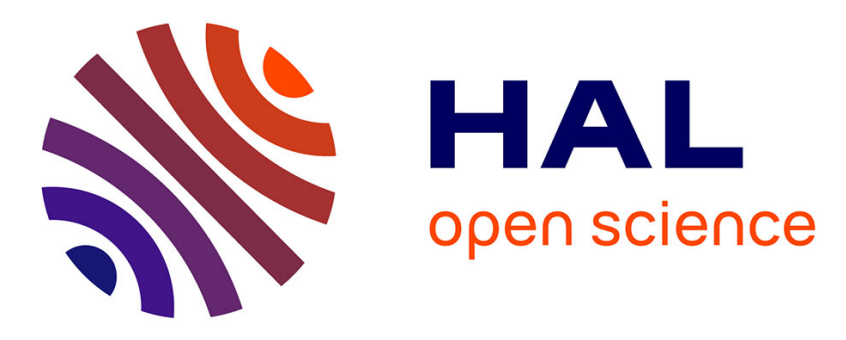

\title{
Mineral cathodic electro-precipitation and its kinetic modelling in thin-film microfluidic reactor during advanced electro-oxidation process
}

Faidzul Hakim Adnan, Emmanuel Mousset, Steve Pontvianne, Marie-Noëlle Pons

\section{To cite this version:}

Faidzul Hakim Adnan, Emmanuel Mousset, Steve Pontvianne, Marie-Noëlle Pons. Mineral cathodic electro-precipitation and its kinetic modelling in thin-film microfluidic reactor during advanced electrooxidation process. Electrochimica Acta, 2021, 387, pp.138487. 10.1016/j.electacta.2021.138487 . hal03429792

\section{HAL Id: hal-03429792 \\ https://hal.science/hal-03429792}

Submitted on 15 Nov 2021

HAL is a multi-disciplinary open access archive for the deposit and dissemination of scientific research documents, whether they are published or not. The documents may come from teaching and research institutions in France or abroad, or from public or private research centers.
L'archive ouverte pluridisciplinaire HAL, est destinée au dépôt et à la diffusion de documents scientifiques de niveau recherche, publiés ou non, émanant des établissements d'enseignement et de recherche français ou étrangers, des laboratoires publics ou privés.

\section{(1) (1) $\$$}

Distributed under a Creative Commons Attribution - NonCommercial - NoDerivatives| 4.0 
process

5 Faidzul Hakim ADNAN ${ }^{1}$, Emmanuel MOUSSET ${ }^{1, *}$, Steve PONTVIANNE ${ }^{1}$, Marie-Noëlle PONS ${ }^{1,2}$

6

7

9

10

${ }^{1}$ Laboratoire Réactions et Génie des Procédés, Université de Lorraine, CNRS, LRGP, F-54000 Nancy, France

${ }^{2}$ LTSER-LRGP, CNRS, Université de Lorraine, F-54000 Nancy, France

\author{
FOR CONSIDERATION
}

*Contact of corresponding author: emmanuel.mousset@enrs.fr 
- Local cathodic alkalization occurs predominantly due to $\mathrm{H}_{2} \mathrm{O}$ reduction not $\mathrm{O}_{2}$

- Electromigration does not influence electro-precipitation within the conditions

- $\mathrm{Mg}(\mathrm{OH})_{2}$ electro-precipitation depends only on applied current density

- Gas evolution and $\mathrm{Mg}^{2+}$ ion decrease $\mathrm{CaCO}_{3}$ electro-precipitation

30 


\section{ABSTRACT}

It is presented for the first time the occurrence and modelling of cathodic mineral electro-precipitation in microfluidic thin-film configuration of electrochemical advanced oxidation process (EAOP), in order to better understand and predict the cathode's scaling when treating water containing $\mathrm{Mg}^{2+}$ and $\mathrm{Ca}^{2+}$. Upon a systematic study, the main results show that when an inter-electrode distance of 500 $\mu \mathrm{m}$ is used at $4 \mathrm{~mA} \mathrm{~cm}^{-2}$, local alkalization on cathode surface occurs despite the absence of dissolved $\mathrm{O}_{2}$ suggesting that it takes place due predominantly to water reduction (current efficiency $>99 \%$ ) and not dissolved $\mathrm{O}_{2}$ reduction. Moreover, electromigration phenomenon could be neglected when varying ionic strength from 0.02 to $0.1 \mathrm{~mol} \mathrm{~L}^{-1}$, while diffusion was the kinetic rate-limiting step. In addition, $\mathrm{Ca}(\mathrm{OH})_{2}$ and $\mathrm{MgCO}_{3}$ precipitates were not formed under all investigated conditions. $\mathrm{Mg}(\mathrm{OH})_{2}$ electro-precipitation was found to be highly dependent on current density, but independent of other ionic species jointly present in electrolyte. $\mathrm{Mg}(\mathrm{OH})_{2}$ precipitated once interfacial $\mathrm{pH}$ of 10.2 was reached. More $\mathrm{CaCO}_{3}$ was electro-precipitated at lower current density (ca. 7.2\%) owing to more vigorous gas evolution when higher current density was applied. $12 \%$ less $\mathrm{CaCO}_{3}$ electroprecipitation was found in the presence of $\mathrm{Mg}^{2+}$ confirming its inhibiting effect towards $\mathrm{CaCO}_{3}$ scaling. The mathematical model proposed could fit well the experimental curves (Root mean square error $(\mathrm{RMSE})<0.1163)$ and permit to predict the evolution of concentration of depositing species (i.e. $\mathrm{Mg}^{2+}, \mathrm{Ca}^{2+}$ and $\mathrm{CO}_{3}{ }^{2-}$ ). Furthermore, the role of hydroxyl radicals $\left({ }^{\circ} \mathrm{OH}\right)$ produced at borondoped diamond (BDD) anode could be neglected upon the applied conditions, meaning that the outcome of this study is reliable across all types of water containing $\mathrm{Mg}^{2+}, \mathrm{Ca}^{2+}$ and/or $\mathrm{CO}_{3}{ }^{2-}$ in compliance to their ubiquity when it is to be treated by electrolysis in general.

Keywords: advanced oxidation process, electro-oxidation, electro-precipitation, microfluidic, scaling 


\section{Introduction}

Occurrence of bio-recalcitrant pollutants in the effluent of municipal or industrial wastewater treatment plants (WWTPs) has been raising concerns amongst different stakeholders in the field of environment and ecology. More and more organic pollutants traceable in the wastewater have been categorized as emerging pollutants due to their recalcitrance property and potential toxicity to living organisms [1, 2]. In the objective of elimination of persistent pollutants in aquatic environment and for water reuse purpose, additional treatment to the effluent of WWTPs seems obligatory. A variety of supplementary treatments has been proposed across literature and the majority of them are based on the fundamentals of chemical oxidation where strong oxidants are involved in the degradation of pollutants. Classical processes such as chlorination, ozonation and advanced oxidation processes (AOPs) (e.g. ozonation, peroxonation, heterogeneous photocatalysis and (photo)-Fenton processes) are to some extent well established to degrade effectively contaminants in aqueous media [3]. Nevertheless, their efficiency comes with firstly high price tag [4] and secondly the prerequisite of adding chemical reagents into the media to be treated.

Electrochemical advanced oxidation processes (EAOPs) have also been reported to remove recalcitrant organic pollutants $[\mathbf{5}, \mathbf{6}]$. A huge boost to the AOPs is that EAOPs do not necessarily require the addition of chemical reagents since strong hydroxyl radical oxidants $\left({ }^{\bullet} \mathrm{OH}\right)$ are electrogenerated continuously in-situ [7]. Owing to the development of diamond-based anode, higher degree of electrochemical oxidation of organic contaminants has been reached $[\mathbf{8}, \mathbf{9}]$. Furthermore, the application of microfluidic reactor within the framework of EAOPs has spurred the capability of wastewater treatment [10-14]. It allows mineralization of organic pollutants without the addition of supporting electrolyte. The micrometric inter-electrode distance vastly accommodates the phenomenon of limitation by mass transfer and ohmic resistance [15] in the case of effluent having relatively low ionic conductivity [16]. 
In spite of that, there is a major drawback within the application of EAOPs and more generally electrolysis to treat wastewater. While treating water of varying concentrations of calcium $\left(\mathrm{Ca}^{2+}\right)$ and magnesium $\left(\mathrm{Mg}^{2+}\right)$ ions), a layer of insulating deposit can be formed on the surface of cathode. Despite low concentration of $\mathrm{Ca}^{2+}$ and $\mathrm{Mg}^{2+}$ in an effluent, in case of the operation of electrochemical cells in continuous-mode such, most of the time, encountered in industrial applications, the deposit progressively passivates the whole electrode surface. Sequencing polarity inversion might be applied as counter-measure but it might take a toll on treatment efficacy, duration of operation and overall operational cost. Furthermore, cathode in operation must be able to tolerate high anodic current during the inverted polarization step given the fact that some cathode materials have been reported to be corroded in such conditions [17]. Upon treating water with high $\mathrm{Ca}^{2+}$ and $\mathrm{Mg}^{2+}$ content, sequencing inversion of polarity might not be the best strategy since the passivation of electrode occurs anyhow. Eventually, without regular intervention, electrochemical cells become very inefficient or probably are no longer operational.

The mechanism of formation of deposits has been well established in the literature $[\mathbf{1 8 ,}$ 19]. When the electrode is polarized at a sufficiently negative potential, dissolved oxygen $\left(\mathrm{O}_{2}\right)$ is reduced to hydroxide ions $\left(\mathrm{OH}^{-}\right)$according to Eq. (1), resulting in an increase of local $\mathrm{pH}[\mathbf{2 0}, \mathbf{2 1}]$.

$\mathrm{O}_{2}+2 \mathrm{H}_{2} \mathrm{O}+4 \mathrm{e}^{-} \rightarrow 4 \mathrm{OH}^{-}$

At a more cathodic potential, reduction of solvent $\left(\mathrm{H}_{2} \mathrm{O}\right)$ can take place according to Eq. (2) which also produces hydroxide ions as well as hydrogen gas $\left(\mathrm{H}_{2}\right)$.

$2 \mathrm{H}_{2} \mathrm{O}+2 \mathrm{e}^{-} \rightarrow \mathrm{H}_{2}+2 \mathrm{OH}^{-}$

As shown in Eqs. (3)-(4), in the presence of $\mathrm{Mg}^{2+}$ and $\mathrm{Ca}^{2+}$, deposits of hydroxide can be produced. Moreover, the $\mathrm{pH}$ increment also shifts thermodynamic ratio of carbonates/bicarbonates (Eq. (5)) favoring the production of carbonate scales as written in Eqs. (6)-(7). 
102

103

104

105

106

107

108

$\mathrm{Mg}^{2+}+2 \mathrm{OH}^{-} \leftrightarrow \mathrm{Mg}(\mathrm{OH})_{2}$

$\mathrm{Ca}^{2+}+2 \mathrm{OH}^{-} \leftrightarrow \mathrm{Ca}(\mathrm{OH})_{2}$

$\mathrm{OH}^{-}+\mathrm{HCO}_{3}^{-} \leftrightarrow \mathrm{H}_{2} \mathrm{O}+\mathrm{CO}_{3}^{2-}$

$\mathrm{Ca}^{2+}+\mathrm{CO}_{3}{ }^{2-} \leftrightarrow \mathrm{CaCO}_{3}$

$\mathrm{Mg}^{2+}+\mathrm{CO}_{3}^{2-} \leftrightarrow \mathrm{MgCO}_{3}$

Different studies have already demonstrated the formation of aforementioned deposits in electrochemical cell while operating with different types of water with varying contents of $\mathrm{Ca}^{2+}$ and $\mathrm{Mg}^{2+}$. They are characterized by their source and application domain: synthetic water for cooling system in cooling towers and oil refineries $[\mathbf{2 2}, \mathbf{2 3}]$, artificial $[\mathbf{2 4}, \mathbf{2 5}]$ and natural groundwater $[\mathbf{2 6}$, 27], mineral potable water $[\mathbf{2 8}, \mathbf{2 9}]$, artificial $[\mathbf{1 9}, \mathbf{3 0 - 3 2}]$ and real seawater $[33,34]$. Interestingly, the reported works were all conducted on the classical rotating disk electrode (RDE) possessing effective exposed surface area of $0.2 \mathrm{~cm}^{2}[19,24-28,30,33], 0.5 \mathrm{~cm}^{2}[22,23,35], 1 \mathrm{~cm}^{2}[32,36,37]$ and 1.5 $\mathrm{cm}^{2}$ [31]. Either carbon steel, gold or stainless steel was used as the working electrode playing the role of cathode. To the best of authors' knowledge, the study of electro-precipitation outside aforementioned configuration is scarce.

Due to the omnipresence of calcium and magnesium in water, further study to understand and more particularly to avoid the formation of insulating deposition at larger scale seems primordial. It is within this context that a detailed investigation has been carried out to understand the influence of electrolytic composition towards the formation of mineral deposits on electrode surface during EAOP. The objective is to establish operating conditions in-which scaling does not occur, or, is minimized owing to the benefits attributed by a microfluidic cell. Moreover, addition of chemical reagents is no longer compulsory in micro-reactor; hence, interference possibly originating from the supporting electrolyte is avoided. Magnesium hydroxide $\left(\mathrm{Mg}(\mathrm{OH})_{2}\right)$, calcium carbonate $\left(\mathrm{CaCO}_{3}\right)$ and 
magnesium carbonate $\left(\mathrm{MgCO}_{3}\right)$ deposits are studied due to the ubiquity of $\mathrm{Mg}^{2+}, \mathrm{Ca}^{2+}$ and $\mathrm{HCO}_{3}{ }^{-}$ $/ \mathrm{CO}_{3}{ }^{2-}$ ions in water sources. Results presented in this paper are the first to elucidate the phenomenon of passivation in microfluidic reactor, a configuration very distinctive to those reported in the literature where RDE were used as working electrode. The geometry and configuration of microfluidic cell adopted in this work are closely representative to reactors used in industries. Notably, the difference between electrode surface in this present study is 25 to 250 times bigger compared to RDEs $\left(0.2\right.$ to $\left.2 \mathrm{~cm}^{2}\right)$ used in the literature. The present design is more adapted for further applications on a larger scale. Synthetic water is used in this work, but it closely mimics the average characteristic of effluent of municipal WWTPs particularly the concentration of $\mathrm{Ca}^{2+}, \mathrm{Mg}^{2+}$ and carbonates as well as $\mathrm{pH}$ and ionic conductivity. Furthermore, it is the first time that the influence on electro-precipitation of hydroxyl radicals produced at high $\mathrm{O}_{2}$ evolution overvoltage anode is studied. Novel theoretical models are developed in this paper where the objectives are two-fold; first, assumptions made to establish the models lead to a better understanding of the mechanism of mineral electro-precipitation if they occur. Second, these models are the first to be reported to predict the evolution of electro-precipitating ions, particularly under the configuration of thin-film microfluidic reactor.

\section{Experimental}

\subsection{Chemicals}

Calcium sulfate dihydrate $(>90 \%)$, magnesium sulfate heptahydrate $(>98 \%)$, sodium hydrogenocarbonate $(>99.5 \%)$ and sodium sulfate $(>97 \%)$ were purchased from VWR International (Fontenay-sous-Bois, France). Sulfuric acid (95-97\%) was obtained from Sigma Aldrich (SaintQuentin-Fallavier, France). Sodium hydroxide (1 N) was provided by Honeywell Fluka (Seelze, Germany). Titanium (IV) oxysulfate-sulfuric acid (27-31\%) solution for hydrogen peroxide $\left(\mathrm{H}_{2} \mathrm{O}_{2}\right)$ detection was purchased from Sigma Aldrich (Saint-Quentin-Fallavier, France). These chemical reagents were used as purchased without further treatment. 


\subsection{Preparation of electrolyte}

151 Electrolyte with and without carbonates contained sources of $\mathrm{Ca}^{2+}\left(150 \mathrm{mg} \mathrm{L}^{-1}\right)$ and $\mathrm{Mg}^{2+}\left(5 \mathrm{mg} \mathrm{L}^{-1}\right)$ 152 dissolved in ultrapure water $(18.2 \mathrm{M} \Omega \mathrm{cm})$ provided by PureLab ELGA Classic water purification

153

154

155

156

157

158

159

160

161

162

163

164

165

166

167

168

169

170

171

172

173

174 system (Veolia Water, Antony, France). Electrolyte with carbonates contained a concentration of 60 $\mathrm{mg}-\mathrm{C} \mathrm{L}^{-1}$. Initial values of $\mathrm{pH}$ and ionic conductivity were always adjusted to 7.6 and $1000 \mu \mathrm{S} \mathrm{cm}^{-1}$ respectively. A small quantity of sodium sulfate $\left(1.4\right.$ to $\left.5 \mathrm{mmol} \mathrm{L}^{-1}\right)$ was added when required in order to reach a constant ionic conductivity and strength $\left(0.02 \mathrm{~mol} \mathrm{~L}^{-1}\right)$ for suitable comparison. The artificial WWTP effluent properties are representative to the average characteristics of effluent from the outlet of municipal WWTPs.

\subsection{Electrochemical system}

The effluent $(0.5 \mathrm{~L})$ to be treated was stored in a double-jacket stainless steel reservoir connected to a thermostatic bath in order to ensure a working temperature of $25^{\circ} \mathrm{C}$ (Bioblock Scientific, PolyScience, Niles, IL, USA). A peristaltic pump (Masterflex, Cole-Parmer, Vernon Hills, IL, USA) was used to circulate the solution. pH (Mettler Toledo InPro 4260i) and conductivity (Mettler Toledo InPro 7100i) were measured at regular time. The electrochemical cell was similar to the one described in previous work [16]. It consisted of a planar-electrodes filter-press type cell. Its body was made onsite and made of poly(methyl methacrylate) (PMMA). The material is chemically and thermally resistant in the applied operating conditions. Rubber seals were designed, built-in, to provide tightness and avoid leakage. Planar electrodes were used as anode and cathode. Double-sided boron-doped diamond (BDD) coated on Niobium ( $\mathrm{Nb}$ ) substrate (DiaCCon, Fürth, Germany) or Platinum plate (Ögussa, Vienna, Austria) with $50 \mathrm{~cm}^{2}$ effective surface area each were used as anode. Stainless steel (Gantois Industries, Saint-Dié-des-Vosges, France) with the same effective surface area $\left(50 \mathrm{~cm}^{2}\right)$ was used as cathode. Prior to utilization, stainless steel was preconditioned chemically by soaking it in sulfuric acid solution of $0.25 \mathrm{M}$. Non-conducting spacer made of polytetrafluoroethylene (PTFE) (Bohlender, Grünsfeld, Germany) was placed in-between to avoid contact between anode and 
cathode. This spacer with micrometric thickness of $500 \mu \mathrm{m}$ was used across this work, hence defining inter-electrode distance of electrochemical cell. Electrolysis was carried out using a power supply HMP4040 (Rohde \& Schwarz, Meudon-la-Forêt, France). The influence of two sufficiently different regions of current density were investigated in this work, i.e. 0.4 and $4 \mathrm{~mA} \mathrm{~cm}^{-2}$. The latter was selected because it has been defined as optimal current density from previous work where similar reactor setting was used to degrade pharmaceutical pollutants [16]. All experiments were carried out at least in duplicate to ensure reproducibility.

In preliminary experiments, two blank solutions were used. One composed of only sulfates $(6.65$ mmol L $\left.{ }^{-1}\right)$ and another one containing carbonates at $60 \mathrm{mg}-\mathrm{C} \mathrm{L}^{-1}$ with $\mathrm{Na}_{2} \mathrm{SO}_{4}\left(5 \mathrm{mmol} \mathrm{L}^{-1}\right)$ as supporting electrolyte. Both blank electrolytes possessed similar initial $\mathrm{pH}$ value (7.6) and ionic strength of $0.02 \mathrm{~mol} \mathrm{~L}^{-1}$. Under another preliminary study where an absence of dissolved $\mathrm{O}_{2}$ was sought for the entire experiment, effluent in reservoir was bubbled with nitrogen gas $\left(\mathrm{N}_{2}\right)$ while it was recirculating through the pilot initiating from $30 \mathrm{~min}$ before electrolysis until the end of experiment. $500 \mu \mathrm{m}$ inter-electrode distance and the highest current density condition $\left(4 \mathrm{~mA} \mathrm{~cm}^{-2}\right)$ were implemented for preliminary experiments.

\subsection{Analytical methods}

Evolutions of $\mathrm{Ca}$ and $\mathrm{Mg}$ elements concentration were monitored, after filtering the samples using Phenex $0.45 \mu \mathrm{m}$ filter (Phenomenex, Le Pecq, France), via inductively coupled plasma optical emission spectroscopy (ICP-OES) Thermo iCAP 6000 (Thermo Fisher, Illkirch-Graffenstaden, France). The calibration was performed according to PlasmaCAL Custom Standard method (SCP Sciences) using a certified multi-element solution (1000 mg L ${ }^{-1}$, SCP Sciences, Villebon-sur-Yvette, France). $\mathrm{Ca}$ and $\mathrm{Mg}$ elements measured by ICP-OES were assimilated to $\mathrm{Ca}^{2+}$ and $\mathrm{Mg}^{2+}$ when dissolved in solution. 
198 The concentration of sulfate $\left(\mathrm{SO}_{4}{ }^{2-}\right)$ was measured using ionic chromatography Dionex ICS 6000

199 (Thermo Fisher, Noisy-Le-Grand, France). Its calibration curve was obtained from a series of 200 different known concentration of $\mathrm{SO}_{4}{ }^{2-}$ prepared from a standard solution of $1000 \mu \mathrm{g} \mathrm{mL}^{-1}$. The anion 201 exchange column IC Dionex ${ }^{\mathrm{TM}}$ IonPac $^{\mathrm{TM}}$ AS18 (Thermo Fisher, Noisy-Le-Grand, France) equipped 202 with a column guard was used. The column was kept at $23^{\circ} \mathrm{C}$. An aliquot of $15 \mu \mathrm{L}$ of sample was 203 injected passing through the column. The temperature of samples tray was maintained at $20^{\circ} \mathrm{C}$. The 204 ICS 6000 was equipped with a conductivity detector for detection system and it was kept constant at 205 $35^{\circ} \mathrm{C}$. The mobile phase rate was set at $1 \mathrm{~mL} \mathrm{~min}^{-1}$.

Total inorganic carbon (TIC) was measured using a TOC-meter V $_{\text {CSH }}$ TC/TN (Shimadzu, Marne-La207 Vallée, France). A TIC standard solution of $1000 \mu \mathrm{g} \mathrm{mL}^{-1}$ (TechLab, Metz, France) was used for calibration and control.

Hydrogen peroxide $\left(\mathrm{H}_{2} \mathrm{O}_{2}\right)$ concentration was measured via complexing $\mathrm{H}_{2} \mathrm{O}_{2}-\mathrm{Ti}^{4+}$ method [38]. UV2600 spectrophotometer (Shimadzu, Marne-La-Vallée, France) was used to detect maximum absorbance of the complex at $410 \mathrm{~nm}$ wavelength. $\mathrm{H}_{2} \mathrm{O}_{2}$ concentration was deduced according to the Beer-Lambert law from a calibration curve established with the use of standard $\mathrm{H}_{2} \mathrm{O}_{2}$ solutions.

Linear scan voltammetry (LSV), chrono-amperometry and chrono-potentiometry were performed using a potentiostat (Ametek, Massy, France) connected to the designed electrochemical cell. The electrode potential was reported against saturated silver chloride reference electrode (V/SSCE) in this 216 work.

\subsection{Recovery step of Ca and Mg elements}

218 The purpose of this step was to support the monitoring of the evolution of $\mathrm{Ca}$ and $\mathrm{Mg}$ concentrations 219 in the electrolyte using ICP-OES. It was assumed that if they decreased in solution over time, they 220 partook in deposition reactions and took solid form. The recovery of $\mathrm{Ca}$ and $\mathrm{Mg}$ from the solid form could assert where the majority of the deposition reactions took place, if they occurred. The recovery 
process was carried out using a solution of sulfuric acid at $0.25 \mathrm{M}$. The objective was to decrease the $\mathrm{pH}$ to re-dissolve the deposits into ionic form. Once completely dissolved, the acid solution was filtered through Phenex $0.45 \mu \mathrm{m}$ filter (Phenomenex, Le Pecq, France) and was analyzed by ICPOES to determine the $\mathrm{Ca}$ and $\mathrm{Mg}$ concentrations. To ensure a thorough recovery of cations that might undergo scaling in different compartment of experimental pilot, the recovery step was performed on cathode, anode as well as pilot tubing. Hence, knowing the initial and final concentration of cations in the electrolyte, mass balance of cations could be performed to observe the distribution of deposition formed in and out of the electrochemical reactor in addition to attesting a quasi-complete recovery of cations.

Theorem of conservation of mass tells that the sum of mass $i$ element $(\mathrm{Ca}$ and $\mathrm{Mg}$ ) recovered at different compartment of experimental pilot at the end of experiment should be equal to the initial mass of $i$ present in electrolyte before the electrolysis, if there is no loss in the closed system. Mass balance and percentage recovery of $i$ are then defined in Eq. (8) and Eq. (9), respectively:

$m_{\text {recovered }}=m_{f, \text { elec }}+m_{\text {anode }}+m_{\text {cathode }}+m_{\text {tube }}$

$\left(m_{\text {recovered }} / m_{i, e l e c}\right) \times 100=\%$ recovery

where $m_{\text {recovered }}$ is the total mass (in $\mathrm{mg}$ ) of $i$ recovered from different compartment, $m_{i, e l e c}$ the initial mass of $i$ element in electrolyte before electrolysis, $m_{f, e l e c}$ the mass of $i$ that remains in electrolyte at the end of electrolysis, $m_{\text {anode }}$ the mass of $i$ recovered from the surface of anode, $m_{\text {cathode }}$ the mass of $i$ recovered from the surface of cathode and $m_{\text {tube }}$ the mass of $i$ recovered from the surface of tubing of pilot.

\section{Modelling}

\subsection{Electrolyte containing $\mathrm{Mg}^{2+}$ and $\mathrm{Ca}^{2+}$}


$\mathrm{Mg}^{2+}$ and $\mathrm{Ca}^{2+}$ react with $\mathrm{OH}^{-}$to produce precipitates of $\mathrm{Mg}(\mathrm{OH})_{2}$ and $\mathrm{Ca}(\mathrm{OH})_{2}$ when the product of concentrations of both cations with $\mathrm{OH}^{-}$exceeds the constants of solubility of $\mathrm{Mg}(\mathrm{OH})_{2}\left(\mathrm{~K}_{\mathrm{S}, \mathrm{Mg}(\mathrm{OH})_{2}}\right)$ $\left(K_{S, M g(O H)_{2}}=5.61 \times 10^{-12}[39,40]\right)$ and of $\mathrm{Ca}(\mathrm{OH})_{2}\left(K_{S, \mathrm{Ca}(\mathrm{OH})_{2}}\right)\left(K_{\mathrm{S}, \mathrm{Ca}(\mathrm{OH})_{2}}=5.00 \times 10^{-6}[39,40]\right)$ respectively. Knowing $\mathrm{Mg}^{2+}$ and $\mathrm{Ca}^{2+}$ concentrations in the system, the concentration of $\mathrm{OH}^{-}$at which its product reaches the $\mathrm{K}_{\mathrm{S}, \mathrm{Mg}(\mathrm{OH})_{2}}$ and $\mathrm{K}_{\mathrm{S}, \mathrm{Ca}(\mathrm{OH})_{2}}$ values, respectively, can be calculated. It is noted as critical $\mathrm{OH}^{-}$concentration $\left(\mathrm{OH}_{\text {crit }}^{-}\right)$.

During the electrolysis, $\mathrm{OH}^{-}$ions are produced on cathode by reduction of either dissolved $\mathrm{O}_{2}$ via 4electrons reaction (Eq. (1)) and/or water via 2-electrons reaction (Eq. (2)). Since both reactions took place in parallel on cathode in our system under the applied current densities, they have been considered as competing reactions. $C E_{\mathrm{O}_{2}}$ and $C E_{\mathrm{H}_{2} \mathrm{O}}$ terms were used to proportionate the current efficiency as a result of the reduction of $\mathrm{O}_{2}$ and $\mathrm{H}_{2} \mathrm{O}$ respectively. The rate of production of $\mathrm{OH}^{-}$ $\left(r_{\mathrm{OH}^{-}}\right)$on cathode in batch mode can thus be written as in Eq. (10):

$r_{\mathrm{OH}^{-}}=+\frac{d\left[\mathrm{OH}^{-}\right]}{d t}=\frac{v_{\mathrm{O}_{2}} j_{a p p}}{n_{\mathrm{O}_{2}} \mathrm{~F}} C E_{\mathrm{O}_{2}}+\frac{\alpha v_{\mathrm{H}_{2} \mathrm{O}} j_{a p p}}{n_{\mathrm{H}_{2} \mathrm{O}} \mathrm{F}} C E_{\mathrm{H}_{2} \mathrm{O}}$

where $v_{\mathrm{O}_{2}}$ and $v_{\mathrm{H}_{2} \mathrm{O}}$ are the stoichiometry coefficient of $\mathrm{OH}^{-}$via reaction of reduction of $\mathrm{O}_{2}(\mathbf{E q}$. (1)) and $\mathrm{H}_{2} \mathrm{O}$ (Eq. (2)) respectively, while $n_{\mathrm{O}_{2}}$ and $n_{\mathrm{H}_{2} \mathrm{O}}$ are their number of electrons involved in those faradaic reactions, $j_{a p p}$ is the applied current density in $\mathrm{mA} \mathrm{cm}{ }^{-2}$ and $\mathrm{F}$ is the Faraday constant $(96,485$ $\left.\mathrm{C} \mathrm{mol}^{-1}\right) . \alpha$ is a corrective term $(\alpha<1)$ assigned to the faradaic production of $\mathrm{OH}^{-}$which occurs concomitantly with physical evolution of gas bubbles on cathode surface at high applied current density. In accordance to Eq. (2), $\mathrm{H}_{2}$ gas also evolves when $\mathrm{H}_{2} \mathrm{O}$ is reduced to $\mathrm{OH}^{-} . \mathrm{H}_{2}$ gas evolution is more intense when higher current density value is used, according to the Faraday's law. Gas evolution on cathode surface contributes to two major consequences; firstly, less surface area could be available for mineral deposition on cathode surface [41]. Secondly, it could promote detachment of deposits occurring on the electrode $[42,43]$. 
267 On the surface of cathode, $\mathrm{OH}^{-}$ions are produced abundantly and continuously. Water is the solvent 268 of electrolyte thus its electrochemical reduction is limitless. Meanwhile, dissolved $\mathrm{O}_{2}$ are not only 269 consumed on cathode (Eq. (1)), but it is also concomitantly produced on anode through water 270 oxidation (Eq. (11)).

$2712 \mathrm{H}_{2} \mathrm{O} \rightarrow \mathrm{O}_{2}+4 \mathrm{H}^{+}+4 e^{-}$

272 In microfluidic configuration, the distance between cathode and anode is very small thus the 273 replenishment of dissolved $\mathrm{O}_{2}$ could take place continuously [44]. As a result, once $\mathrm{OH}_{\text {crit }}^{-}$is reached, $274 \mathrm{OH}^{-}$concentration is considered constant and it does not vary whilst reacting with $\mathrm{Mg}^{2+}$ and $\mathrm{Ca}^{2+}$ 275 because the concentration of $\mathrm{OH}^{-}$is significantly larger and in excess compared to the cations 276 concentrations. In addition, it is assumed that $\mathrm{Mg}^{2+}$ and $\mathrm{Ca}^{2+}$ were not reduced or oxidized by direct 277 electrochemical reduction or oxidation, so that their oxidation state remained constant all along the 278 electrolysis [45].

279 Hence, according to Eqs. (3)-(4), the rate of reaction of $\mathrm{Mg}^{2+}$ and $\mathrm{Ca}^{2+}$ can be written according to 280 Eq. (12) and Eq. (13) respectively:

$r_{\mathrm{Mg}^{2+}}=-r_{\mathrm{Mg}(\mathrm{OH})_{2}}=-k_{\mathrm{Mg}(\mathrm{OH})_{2}}\left[\mathrm{Mg}^{2+}\right]\left[\mathrm{OH}^{-}\right]^{2}$

$r_{\mathrm{Ca}^{2+}}=-r_{\mathrm{Ca}(\mathrm{OH})_{2}}=-k_{\mathrm{Ca}(\mathrm{OH})_{2}}\left[\mathrm{Ca}^{2+}\right]\left[\mathrm{OH}^{-}\right]^{2}$

283 where $k_{\mathrm{Mg}(\mathrm{OH})_{2}}$ and $k_{\mathrm{Ca}(\mathrm{OH})_{2}}$ are the third order rate constants regarding the reaction of precipitation 284 of $\mathrm{Mg}(\mathrm{OH})_{2}$ and $\mathrm{Ca}(\mathrm{OH})_{2}$ respectively in $\mathrm{L}^{2} \mathrm{~mol}^{-2} \mathrm{~s}^{-1}$, while $\left[\mathrm{Mg}^{2+}\right],\left[\mathrm{Ca}^{2+}\right]$ and $\left[\mathrm{OH}^{-}\right]$are the molar 285 concentration (in $\mathrm{mol} \mathrm{L}^{-1}$ ) of $\mathrm{Mg}^{2+}, \mathrm{Ca}^{2+}$ and $\mathrm{OH}^{-}$ions, respectively.

\subsection{Electrolyte containing $\mathrm{Ca}^{2+}$ and $\mathrm{CO}_{3}{ }^{2-}$}

$\mathrm{Ca}^{2+}$ reacts with $\mathrm{CO}_{3}{ }^{2-}$ to form $\mathrm{CaCO}_{3}$ precipitates when the product of concentrations of both ions exceeds the constant of solubility of $\mathrm{CaCO}_{3}\left(K_{S, \mathrm{CaCO}_{3}}\right)\left(K_{S, \mathrm{CaCO}_{3}}=3.36 \times 10^{-9}[\mathbf{4 0}, \mathbf{4 6 - 4 8}]\right)$. 
289 Supersaturation degree (S) of $\mathrm{CaCO}_{3}$ is defined in Eq. (14) and follows by its supersaturation index 290 in Eq. (15) [49, 50].

$291 S=\frac{\left[\mathrm{Ca}^{2+}\right]\left[\mathrm{CO}_{3}^{2-}\right]}{K_{S p, \mathrm{CaCO}_{3}}}$

$292 S I=\log _{10}(S)$

293 Thermodynamically, $\mathrm{CaCO}_{3}$ can precipitate when $\mathrm{S}>1$ ( or $\mathrm{SI}>0$ ). Carbonates concentration can be 294 estimated from TIC measurement that corresponds to the sum of all forms of inorganic carbon (Eq. 295 (16)):

$296 \mathrm{TIC}=\left[\mathrm{H}_{2} \mathrm{CO}_{3}\right]+\left[\mathrm{HCO}_{3}^{-}\right]+\left[\mathrm{CO}_{3}^{2-}\right]$

297 where $\mathrm{H}_{2} \mathrm{CO}_{3}$ is carbonic acid and $\mathrm{HCO}_{3}^{-}$is bicarbonate ion.

298 The inorganic carbon species are linked together by acidity constants $K_{a 1}$ and $K_{a 2}$ given in Eqs. (17)299 (18), respectively.

$300 \quad K_{a 1}=\frac{\left[\mathrm{H}^{+}\right]\left[\mathrm{HCO}_{3}^{-}\right]}{\left[\mathrm{H}_{2} \mathrm{CO}_{3}\right]}$

$301 \quad K_{a 2}=\frac{\left[\mathrm{H}^{+}\right]\left[\mathrm{CO}_{3}^{2-}\right]}{\left[\mathrm{HCO}_{3}^{-}\right]}$

302 Their ratios are therefore governed by the solution pH. $p K_{a 1}$ and $p K_{a 2}$ values are 6.3 and 10.4 [51], 303 respectively. Under the range of our $\mathrm{pH}$ operating conditions and at the proximity of cathode surface, 304 the quantity of $\mathrm{H}_{2} \mathrm{CO}_{3}$ is negligible and the expression of TIC can be simplified into Eq. (19).

$305 \mathrm{TIC}=\left[\mathrm{HCO}_{3}^{-}\right]+\left[\mathrm{CO}_{3}^{2-}\right]$

$306 \mathrm{CO}_{3}^{2-}$ concentration is related to the concentration of $\mathrm{OH}^{-}$produced on cathode surface by its 307 equilibrium with $\mathrm{HCO}_{3}{ }^{-}$in agreement with Eq. (5) and Eq. (18). Hence, the evolution of interfacial 
$\mathrm{CO}_{3}{ }^{2-}$ concentration $\left(\left[\mathrm{CO}_{3}^{2-}\right]_{\text {int }, t}\right)$ can be estimated from TIC values by combining Eqs. (10), (18) and (19) giving out an expression in Eq. (20).

$\left[\mathrm{CO}_{3}^{2-}\right]_{\text {int }, t}=\frac{K_{a 2} \times T I C_{t}}{\frac{K_{W}}{\left[\mathrm{OH}^{-}\right]_{t}}+K_{a 2}}$

where $K_{a 2}$ and the concentration of interfacial $\mathrm{CO}_{3}^{2-}, \mathrm{OH}^{-}$and TIC are expressed in $\mathrm{mol} \mathrm{L}^{-1}$ while the equilibrium constant of auto-ionization of water $\left(K_{W}\right)$ is considered equaled to $10^{-14}$ at $25^{\circ} \mathrm{C}$.

According to Eq. (6), the rate of reaction of $\mathrm{Ca}^{2+}$ and $\mathrm{CO}_{3}{ }^{2-}$ producing $\mathrm{CaCO}_{3}$ can be defined as indicated in Eq. (21):

$r_{\mathrm{Ca}^{2+}}=r_{\mathrm{CO}_{3}^{2-}}=-r_{\mathrm{CaCO}_{3}}=-k_{\mathrm{CaCO}_{3}}\left[\mathrm{Ca}^{2+}\right]\left[\mathrm{CO}_{3}^{2-}\right]_{\text {int }}$

where $k_{\mathrm{CaCO}_{3}}$ is the second order rate constant (in $\mathrm{L} \mathrm{mol}^{-1} \mathrm{~s}^{-1}$ ) regarding the reaction of precipitation of $\mathrm{CaCO}_{3}$. Identically to the $\mathrm{Mg}^{2+} / \mathrm{Ca}^{2+}$ system (section 3.1), $\mathrm{OH}^{-}$accumulates at the vicinity of cathode during the electrolysis.

\subsection{Electrolyte containing $\mathrm{Mg}^{2+}$ and $\mathrm{CO}_{3}{ }^{2-}$}

In absence of $\mathrm{Ca}^{2+}, \mathrm{Mg}^{2+}$ can precipitate in the form of $\mathrm{Mg}(\mathrm{OH})_{2}$ upon reaching $\mathrm{OH}_{\text {crit }}^{-}$as well as $\mathrm{MgCO}_{3}$ when the product of concentrations of $\mathrm{Mg}^{2+}$ and $\mathrm{CO}_{3}{ }^{2-}$ exceeds thermodynamic solubility constant of $\mathrm{MgCO}_{3}\left(K_{S, M g C O}\right)\left(K_{S, M g C O}=1.59 \times 10^{-8}[52]\right)$. Local alkalization remains valid at the surface of cathode. Knowing the fact that $\mathrm{Mg}^{2+}$ could participate in the precipitation reactions of $\mathrm{Mg}(\mathrm{OH})_{2}$ and $\mathrm{MgCO}_{3}$, on top of kinetic law defined in Eq. (12), the rate of reaction of $\mathrm{Mg}^{2+}$ can be rewritten in Eq. (22) as follow:

$r_{\mathrm{Mg}^{2+}}=-r_{\mathrm{Mg}(\mathrm{OH})_{2}}-r_{\mathrm{MgCO}_{3}}=-k_{\mathrm{Mg}(\mathrm{OH})_{2}}\left[\mathrm{Mg}^{2+}\right]\left[\mathrm{OH}^{-}\right]^{2}-k_{\mathrm{MgCO}_{3}}\left[\mathrm{Mg}^{2+}\right]\left[\mathrm{CO}_{3}^{2-}\right]$

where $k_{\mathrm{MgCO}_{3}}$ is the second order rate constant (in $\mathrm{L} \mathrm{mol}^{-1} \mathrm{~s}^{-1}$ ) regarding the reaction of precipitation of $\mathrm{MgCO}_{3}$. 


\subsection{Electrolyte containing $\mathrm{Mg}^{2+}, \mathrm{Ca}^{2+}$ and $\mathrm{CO}_{3}{ }^{2-}$}

In the matrix of electrolyte containing $\mathrm{Mg}^{2+}, \mathrm{Ca}^{2+}$ and $\mathrm{CO}_{3}{ }^{2-}$, both $\mathrm{Mg}^{2+}$ and $\mathrm{Ca}^{2+}$ can undergo precipitation in accordance to Eqs. (3)-(4) and Eqs. (6)-(7). The phenomenon of local alkalization remains accurate in this system.

In the presence of $\mathrm{Mg}^{2+}$, depositing $\mathrm{MgOH}_{2}$ consumes $\mathrm{OH}^{-}$over time. The cathodic production of $\mathrm{OH}^{-}$in Eq. (10) is modified taking into account this event as indicated in Eq. (23):

$r_{\mathrm{OH}^{-}}=+\frac{d\left[\mathrm{OH}^{-}\right]}{d t}=\frac{v_{\mathrm{O}_{2}} j_{a p p}}{n_{\mathrm{O}_{2}} \mathrm{~F}} C E_{\mathrm{O}_{2}}+\frac{\alpha v_{\mathrm{H}_{2} \mathrm{O} j_{a p p}}}{n_{\mathrm{H}_{2} \mathrm{O}} \mathrm{F}} C_{\mathrm{H}_{2} \mathrm{O}}-2 k_{\mathrm{Mg}(\mathrm{OH})_{2}}\left[\mathrm{Mg}^{2+}\right]\left[\mathrm{OH}^{-}\right]^{2}$

\subsection{Modelling software and fitting evaluation}

Aquasim [53] was used to model the evolution of $\mathrm{Mg}^{2+}, \mathrm{Ca}^{2+}$ and $\mathrm{CO}_{3}{ }^{2-}$. The fitting between experimental data and theoretical model was evaluated using root mean square error (RMSE), model efficiency (ME) and index of agreement (IOA) according to Eq. (24), Eq. (25) and Eq. (26), respectively [54]:

$R M S E=\sqrt{\frac{\sum_{i=1}^{K}\left(y_{i}-y_{i}^{\prime}\right)^{2}}{K}}$

$M E=1-\frac{\sum_{i=1}^{K}\left(y_{i}-y_{i}^{\prime}\right)^{2}}{\sum_{i=1}^{K}\left(y_{i}-y_{M}\right)^{2}}$

$I O A=1-\frac{\sum_{i=1}^{K}\left(y_{i}-y_{i}^{\prime}\right)^{2}}{\sum_{i=1}^{K}\left(\left|y_{i}^{\prime}-y_{M}\right|+\left|y_{i}-y_{M}\right|\right)^{2}}$

where $\mathrm{K}$ is the number of steps of checked values, $y_{i}^{\prime}$ is the experimental value, $y_{i}$ is the corresponding simulated value and $y_{M}$ is the average of simulated value.

\section{Results and discussion}

\subsection{Stability of anions in blank solutions using BDD or Pt anode}


Preliminary experiments were conducted in the microfluidic reactor to check on the behavior of anions ( $\mathrm{SO}_{4}{ }^{2-}$ and $\mathrm{HCO}_{3}{ }^{-} / \mathrm{CO}_{3}{ }^{2-}$ ) during electro-oxidation in the absence of depositing elements. BDD and $\mathrm{Pt}$ anodes were used to verify the involvement of ${ }^{\circ} \mathrm{OH}$ towards any oxidation of anions. The former is well-known for its high overpotential for oxygen evolution reaction (OER). Consequently, physi-sorbed ${ }^{\bullet} \mathrm{OH}$ are produced at anode vicinity $[\mathbf{5 5}, \mathbf{5 6}]$. Contrastingly, the overpotential for OER with $\mathrm{Pt}$ anode is low. Thus ${ }^{\circ} \mathrm{OH}$ is chemi-sorbed on the anode surface, making the radical not available [57].

The evolution of concentration of $\mathrm{SO}_{4}{ }^{2-}$ and TIC are depicted in Fig. 1. It has been noticed that the concentration of both anions remained constant throughout the entire electro-oxidation experiments whether BDD or Pt was used as anode. First deduction that can be made is that $\mathrm{SO}_{4}{ }^{2-}$ and $\mathrm{HCO}_{3}{ }^{-}$ $/ \mathrm{CO}_{3}{ }^{2-}$ anions were stable during the electro-oxidation process whatever the anode employed. It means that they will not interfere if there is occurrence of electro-precipitation on cathode surface. Secondly, under these applied conditions, the formation of oxidizing agent of ${ }^{\bullet} \mathrm{OH}$ did not inflict towards the degradation of $\mathrm{SO}_{4}{ }^{2-}$ and $\mathrm{HCO}_{3}{ }^{-} / \mathrm{CO}_{3}{ }^{2-}$ anions. Anode potential was measured to be +2.40 $\mathrm{V} / \mathrm{SSCE}$ ( or $+2.60 \mathrm{~V} / \mathrm{SHE}$ ), which already hit the standard potential of formation of ${ }^{\bullet} \mathrm{OH}$ when $4 \mathrm{~mA}$ $\mathrm{cm}^{-2}$ is applied. The oxidation conditions were not strong enough to oxidize $\mathrm{SO}_{4}{ }^{2-}$ into peroxydisulfates $\left(\mathrm{S}_{2} \mathrm{O}_{8}{ }^{2-}\right)[58]$ and $\mathrm{CO}_{3}{ }^{2-}$ into peroxydicarbonates $\left(\mathrm{C}_{2} \mathrm{O}_{6}{ }^{2-}\right)[\mathbf{5 9}, \mathbf{6 0}]$ with $\mathrm{SO}_{4}{ }^{--}$and $\mathrm{CO}_{3}{ }^{--}$as intermediates, respectively. Moreover, anion of strong acid such as $\mathrm{SO}_{4}{ }^{2-}$ is very unlikely to form complex with alkaline-earth cations such as $\mathrm{Ca}^{2+}$ and $\mathrm{Mg}^{2+}$ [61]. In overall, ${ }^{\circ} \mathrm{OH}$ involvement in microfluidic reactor set-up did not lead to the oxidation of $\mathrm{SO}_{4}{ }^{2-}$ and $\mathrm{HCO}_{3}{ }^{-} / \mathrm{CO}_{3}{ }^{2-}$ anions in blank electrolytes during electro-oxidation experiments. In overall, the presence of ${ }^{\bullet} \mathrm{OH}$ in our applied microfluidic reactor conditions could thus be omitted from the developed theoretical models and was confirmed further in the next sections. 
(a)

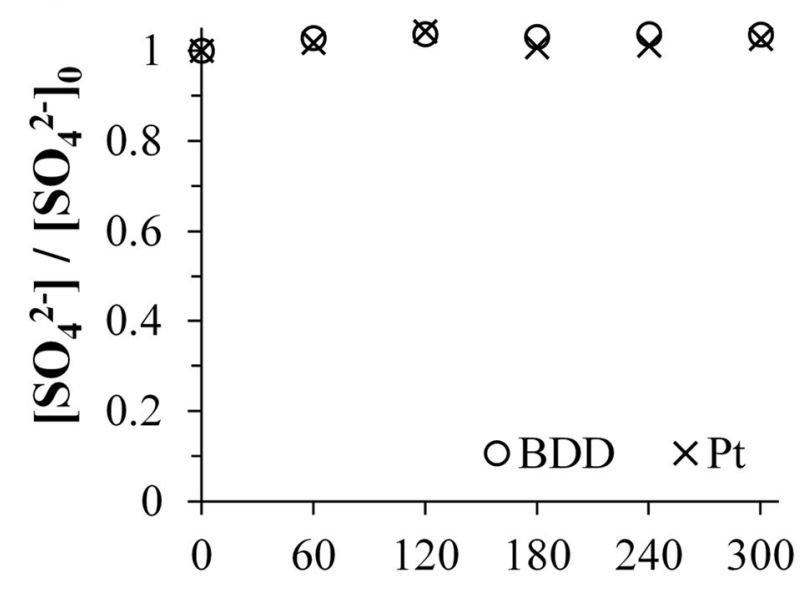

371 this selectivity, since $\mathrm{H}_{2} \mathrm{O}$ could be also oxidized to $\mathrm{O}_{2}$. (b)

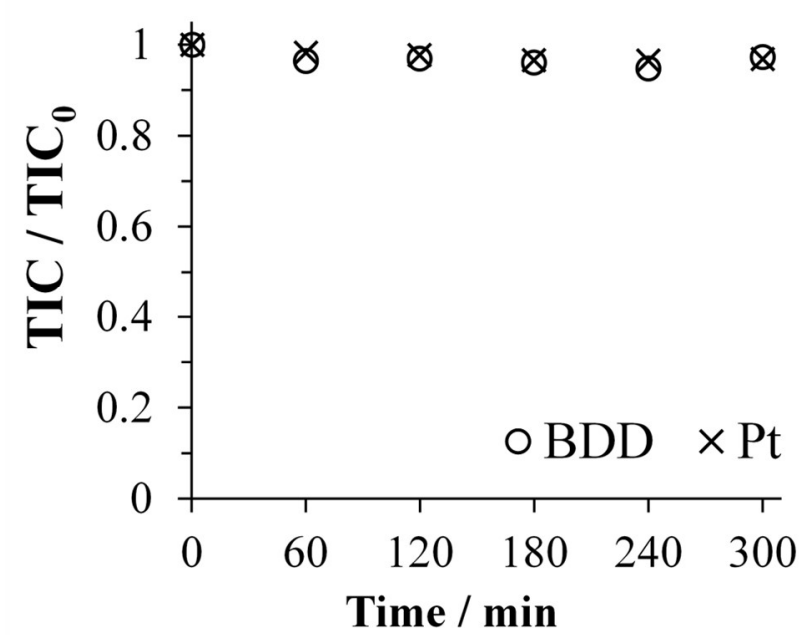

Fig. 1. Evolution of concentration of (a) $\mathrm{SO}_{4}{ }^{2-}$ (in blank solution containing sulfates only) and (b) TIC (in blank solution containing carbonates only) during the electrolysis of blank solutions using BDD $(O)$ or $\mathrm{Pt}(\times)$ as anode. Cathode: stainless steel, ionic strength of both blank solutions: 0.02 mol L-1 applied current density: $4 \mathrm{~mA} \mathrm{~cm}^{-2}$ and inter-electrode distance: $500 \mu \mathrm{m}$.

\subsection{Local alkalization on cathode surface: reactions' selectivity between reduction of dissolved $\mathrm{O}_{2}$ and water}

According to Eq. (1) and Eq. (2) respectively, both dissolved $\mathrm{O}_{2}$ and $\mathrm{H}_{2} \mathrm{O}$ can undergo faradaic reduction generating $\mathrm{OH}^{-}$(Eq. (10)). To identify the weight of contribution of dissolved $\mathrm{O}_{2}$ to produce $\mathrm{OH}^{-}$with respect to local alkalization phenomenon, tests in presence and absence of dissolved $\mathrm{O}_{2}$ were conducted. Under the investigated micrometric distance, anodic activity might be involved in

Fig. 2 plots the evolution of concentration of $\mathrm{Mg}^{2+}, \mathrm{Ca}^{2+}$ and TIC in the experiments with and without dissolved $\mathrm{O}_{2}$. In both cases, the concentration of all species decreased regardless of presence of dissolved $\mathrm{O}_{2}$. This indicates that the initial presence of dissolved $\mathrm{O}_{2}$ was insignificant towards the phenomenon of local alkalization, and consequently towards the formation of deposits on cathode surface. Notably from Fig. 2(a) and Fig. 2(b), it has been deduced that the source of $\mathrm{OH}^{-}$ions came mainly from reduction of water and not from dissolved $\mathrm{O}_{2}$. A slight decrease in the electro- 
389

390

391

392

393

394

395

407

408

precipitation of $\mathrm{Ca}^{2+}$ in absence of dissolved $\mathrm{O}_{2}$ was due to slightly lesser amount of $\mathrm{OH}^{-}$participating in thermodynamic shift of $\mathrm{HCO}_{3}{ }^{-} / \mathrm{CO}_{3}{ }^{2-}$ towards the formation of $\mathrm{CO}_{3}{ }^{2-}$ (Fig. 2(b)). Thus, lesser extent of $\mathrm{CaCO}_{3}$ electro-precipitation was observed.

Under theses setups, the concentration of electrogenerated $\mathrm{H}_{2} \mathrm{O}_{2}$ was measured to further study the contribution of dissolved $\mathrm{O}_{2}$ reduction producing $\mathrm{OH}^{-}$ions in accordance with Eq. (27).

$\mathrm{O}_{2}+2 \mathrm{H}_{2} \mathrm{O}+2 e^{-} \leftrightarrow \mathrm{H}_{2} \mathrm{O}_{2}+2 \mathrm{OH}^{-}$

The $\mathrm{H}_{2} \mathrm{O}_{2}$ production was found to be very small (maximum concentration went up to $1.8 \mu \mathrm{mol} \mathrm{L} \mathrm{L}^{-1}$, data not shown), whatever the applied current density. Most of $\mathrm{H}_{2} \mathrm{O}_{2}$ concentration values fell below the limit of quantification of the method, determined to be $0.8 \mu \mathrm{mol} \mathrm{L} \mathrm{L}^{-1}$. This observation was attributed to the low $\mathrm{H}_{2}$ evolution overvoltage on stainless steel cathode [62]. Similar poor production of $\mathrm{H}_{2} \mathrm{O}_{2}$ on stainless steel cathode was reported by Sopaj et al. [38]. They measured approximately $40 \mu \mathrm{mol} \mathrm{L}-1$ of $\mathrm{H}_{2} \mathrm{O}_{2}$ under their experimental setup when $4.8 \mathrm{~mA} \mathrm{~cm}^{-2}$ was applied [38]. Unlike the configuration presented in our work, compressed air was continuously bubbled under their experimental setup to supply dissolved $\mathrm{O}_{2}$ to promote the Fenton reaction, which explains the difference in measured $\mathrm{H}_{2} \mathrm{O}_{2}$ concentration.

$C E_{\mathrm{O}_{2}}$ and $C E_{\mathrm{H}_{2} \mathrm{O}}$ in Eq. (10) and Eq. (23) were estimated via Eqs. (28)-(29) at each value of current density investigated in this work. Their values are tabulated in Table 1. The calculations are attached as Text $\mathbf{S 1}$ in supplementary materials.

$C E_{O_{2}}=\frac{n_{e}-F N_{O_{2}}}{J_{a p p} t}$

$C E_{\mathrm{H}_{2} \mathrm{O}}=1-C E_{\mathrm{O}_{2}}$

where $n_{e^{-}}$is the number of electron exchanged in Eq. (27), $N_{O_{2}}$ is the quantity of dissolved $\mathrm{O}_{2}$ (in mol) reduced to $\mathrm{H}_{2} \mathrm{O}_{2}$ in Eq. (27), $J_{a p p}$ is the applied current (in A) and $t$ is the electrolysis time. 
Table 1. Estimation of $C E_{\mathrm{O}_{2}}$ and $C E_{\mathrm{H}_{2} \mathrm{O}}$ in faradaic production of $\mathrm{OH}^{-}$on cathode.

\begin{tabular}{cccc}
\hline$j_{\text {app }} / \mathrm{mA} \mathrm{cm}^{-2}$ & $N_{\mathrm{O}_{2}} / \mu \mathrm{mol}$ & $C E_{\mathrm{O}_{2}} / \%$ & $C E_{\mathrm{H}_{2} \mathrm{O}} / \%$ \\
\hline 0.4 & 0.6 & 0.16 & 99.84 \\
\hline 4 & 0.9 & 0.02 & 99.98 \\
\hline
\end{tabular}

412 To conclude, local alkalization on cathode surface principally occurred due to the reduction of $\mathrm{H}_{2} \mathrm{O}$ 413 with only slight involvement of dissolved $\mathrm{O}_{2}$ under our experimental setup. The latter was 414 electrocatalytically reduced to $\mathrm{OH}^{-}$with negligible production of $\mathrm{H}_{2} \mathrm{O}_{2}$ on stainless steel. Our 415 proposed model takes into consideration this observed selectivity given by higher faradaic yield of $416 C E_{\mathrm{H}_{2} \mathrm{O}}$ in producing $\mathrm{OH}^{-}$as deduced in Table 1 when applied to Eq. (10) and Eq. (23). 
(a)

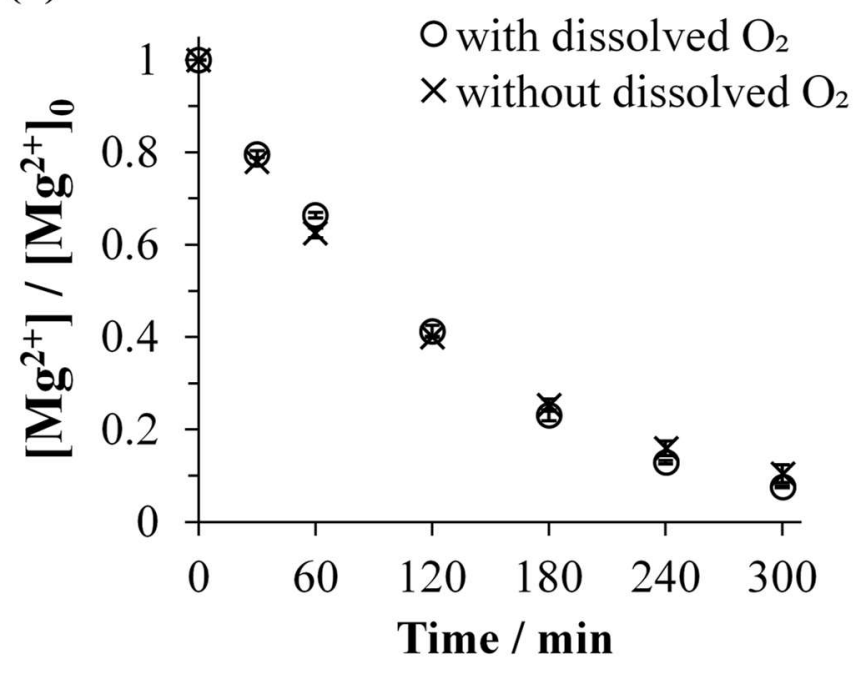

(b)

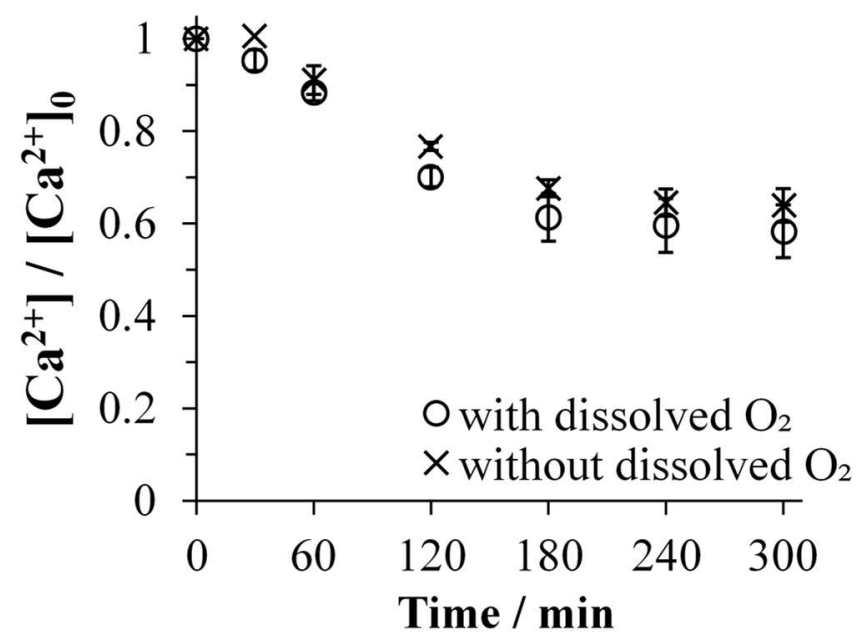

(c)

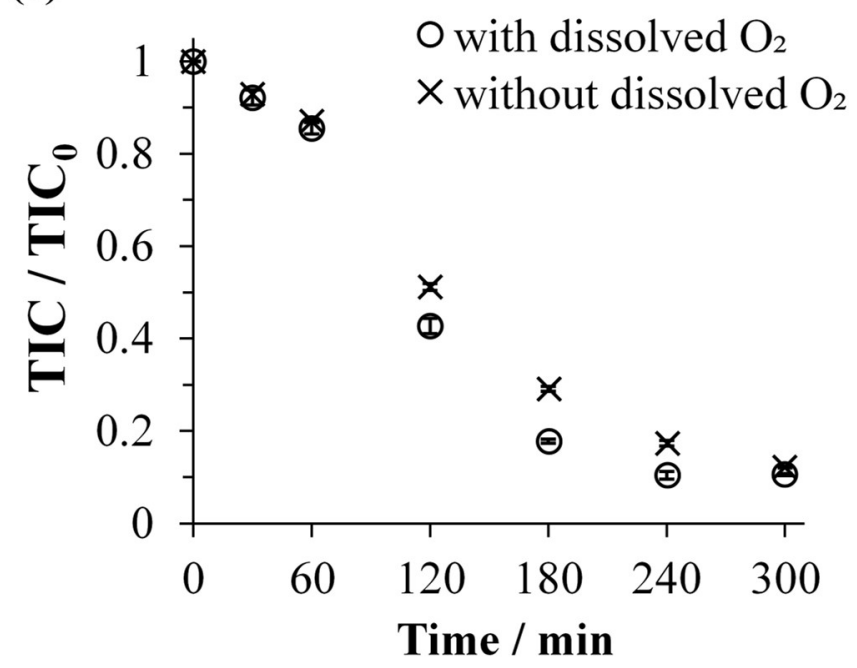

Fig. 2. Evolution of concentration of (a) $\mathrm{Mg}^{2+}$, (b) $\mathrm{Ca}^{2+}$ and (c) TIC during the electrolysis of 419 artificial effluent containing $150 \mathrm{mg} \mathrm{L}^{-1}$ of $\mathrm{Ca}^{2+}, 5 \mathrm{mg} \mathrm{L}^{-1}$ of $\mathrm{Mg}^{2+}$ and $60 \mathrm{mg}-\mathrm{C} \mathrm{L}^{-1}$ of $\mathrm{HCO}_{3}{ }^{-} / \mathrm{CO}_{3}{ }^{2-}$ in absence $(\times)$ (via bubbling with $\mathrm{N}_{2}$ gas) and presence $(\mathrm{O})$ of dissolved $\mathrm{O}_{2}$ throughout the 
experiment. Anode: BDD, cathode: stainless steel, applied current density: $4 \mathrm{~mA} \mathrm{~cm}^{-2}$ and interelectrode distance: $500 \mu \mathrm{m}$.

\subsection{Influence of electromigration of ionic species}

Although calcium and magnesium deposits are formed on the surface of cathode during electrolysis, $\mathrm{Ca}^{2+}$ and $\mathrm{Mg}^{2+}$ do not participate in direct electron transfer to yield $\mathrm{Ca}$ metal $(\mathrm{Ca}(\mathrm{s}))$ and $\mathrm{Mg}$ metal $(\mathrm{Mg}(\mathrm{s}))$ respectively. The reduction of $\mathrm{Ca}^{2+}$ and $\mathrm{Mg}^{2+}$ each by two electrons need to overcome a strong thermodynamic barrier $\left(E_{\mathrm{Ca}^{2+}}^{0} / \mathrm{Ca}_{(s)}=-2.84 \mathrm{~V} / \mathrm{SHE}\right.$ and $\left.E_{M g^{2+}}^{0} / \mathrm{Mg}_{(s)}=-2.356 \mathrm{~V} / \mathrm{SHE}[63]\right)$, and these strong reduction conditions are not involved in the present study (cathode potential determined to be $-1.34 \mathrm{~V} / \mathrm{SHE}$ ). Instead, they reacted chemically with respective counter-ions on the surface of cathode, producing scaling when solubility constant of precipitates was achieved. Despite not being electroactive elements in regard to driving force of potential difference across electrochemical reactor, $\mathrm{Ca}^{2+}$ and $\mathrm{Mg}^{2+}$ mobility towards cathode surface might be involved in the displacement of

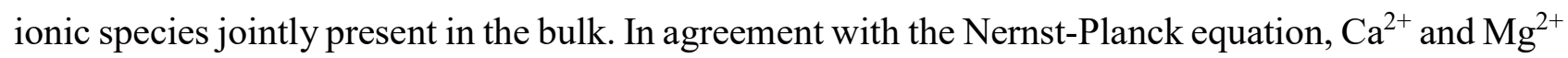
were transported by forced convection thanks to electrolyte flow in-between electrodes. Under stationary conditions, they underwent diffusion from electrolyte bulk through finite boundary layer (i.e. diffusion layer), towards reactive zone at the proximity of cathode surface. Then through migration, they were mobilized to fulfill electro-neutrality on cathode surface as the consequence of local alkalization [64-66]. The two current densities investigated in this study were both above the initial limiting current density (determined to be $0.25 \mathrm{~mA} \mathrm{~cm}^{-2}$ using $\mathrm{j}$ lim calculation $[67,68]$ (Text S2), which was then confirmed with limiting current density plateau on linear scan voltammogram (Fig. S1)) for aforementioned electrochemical cell setup while producing $\mathrm{OH}^{-}$. Hence, electrochemical reactions taking place on the surface of cathode were considered limited by the mass transport. 
444 Therefore, in this section, under constant hydrodynamic parameters, the influence of electromigration 445 of ionic species was investigated by varying the ionic strength of artificial effluent using $\mathrm{Na}_{2} \mathrm{SO}_{4}$ as 446 supporting electrolyte. Table 2 summarizes the values of ionic transference number for the different 447 cases. They were calculated using Eqs. (30)-(31) [69] under the assumption that our electrolytic 448 system complied with the restriction of infinite dilution where interaction between ions was not 449 occurring.

$450 \quad t_{i}=\frac{z_{i} C_{i} u_{i}}{\sum_{i} z_{i} C_{i} u_{i}}$

451 with

$452 \quad u_{i}=\frac{\lambda_{i}}{z_{i} F}$

453 where $t_{i}$ is the transference number, $z_{i}$ the ionic charges, $u_{i}$ the ionic mobility (in $\left.\mathrm{m}^{2} \mathrm{~s}^{-1} \mathrm{~V}^{-1}\right), C_{i}$ the 454 molar concentrations of ionic species (in $\mathrm{mol} \mathrm{L}^{-1}$ ) and $\lambda_{i}$ the ionic molar conductivity (in $\mathrm{S} \mathrm{m}^{2} \mathrm{~mol}^{-}$ $\left.455^{1}\right)$.

456 Table 2. Ionic transference number for artificial effluent containing $150 \mathrm{mg} \mathrm{L}^{-1}$ of Ca ${ }^{2+}, 5 \mathrm{mg} \mathrm{L}^{-1}$ of $457 \mathrm{Mg}^{2+}$ and $60 \mathrm{mg}-\mathrm{C} \mathrm{L}{ }^{-1}$ of TIC without and with addition of $\mathrm{Na}_{2} \mathrm{SO}_{4}$ at different concentrations.

\begin{tabular}{cccccc}
\hline $\begin{array}{l}\text { Ionic } \\
\text { strength } \\
\text { mol L }\end{array}$ & \multicolumn{5}{c}{ Ionic transference number } \\
\cline { 2 - 5 } & $\mathrm{Ca}^{2+}$ & $\mathrm{Mg}^{2+}$ & $\mathrm{Na}^{+}$ & $\mathrm{HCO}_{3}^{-}$ & $\mathrm{SO}_{4}^{2-}$ \\
\hline $\begin{array}{c}0.02 \\
(\text { without } \\
\left.\mathrm{Na}_{2} \mathrm{SO}_{4}\right)\end{array}$ & 0.218 & 0.011 & 0.123 & 0.339 & 0.309 \\
\hline 0.04 & 0.120 & 0.006 & 0.241 & 0.187 & 0.447 \\
\hline 0.10 & 0.050 & 0.002 & 0.325 & 0.077 & 0.545 \\
\hline
\end{tabular}


As can be seen from Table 2, the more $\mathrm{Na}_{2} \mathrm{SO}_{4}$ was added to increase the ionic strength of artificial effluent, the more ionic mobility of $\mathrm{Ca}^{2+}, \mathrm{Mg}^{2+}$ and $\mathrm{HCO}_{3}{ }^{-} / \mathrm{CO}_{3}{ }^{2-}$ were minimized by increasing transport activity of $\mathrm{Na}^{2+}$ and $\mathrm{SO}_{4}{ }^{2-}$.

Fig. 3 depicts the trend of evolution of concentration of $\mathrm{Mg}^{2+}, \mathrm{Ca}^{2+}$ and TIC when the investigated artificial effluent had different ionic strengths. The concentration of each ion decreased over time regardless of value of ionic strength. It seemed to have very little impact on the variation of the concentration of $\mathrm{Ca}^{2+}$ and TIC as previously suggested by Tlili et al., where migration might play some role with respect to only more concentrated species in the system [64]. Standard deviations were calculated between results obtained with the electrolytes with enhanced ionic mobility in comparison to the one without supporting electrolyte. The average values are listed in Table S1. The two highest deviation were obtained in $\mathrm{Mg}^{2+}$ and $\mathrm{TIC}$ concentration with evaluated deviation as low as 0.049 and 0.042 , respectively. Therefore, the ionic strength of electrolyte had minor effect within the range of studied electrolyte concentrations towards the occurring mineral deposition on cathode surface. Electromigration of ionic species other than $\mathrm{Ca}^{2+}, \mathrm{Mg}^{2+}$ and $\mathrm{HCO}_{3}{ }^{-} / \mathrm{CO}_{3}{ }^{2-}$ did not influence the mobility of the precipitating elements in-between electrodes inside microfluidic electrochemical reactor. Mass transport by diffusion was then the rate-limiting factor. Based on these results, the effect of electromigration could be omitted from the theoretical model proposed in section $\mathbf{3}$. The addition of small quantity of supporting electrolyte (from 1.4 to $5 \mathrm{mmol} \mathrm{L}^{-1}$ ) to achieve constant ionic strength across different investigated matrices of electrolyte will not influence the kinetics of mineral electroprecipitation in experimental results presented onwards. 
(a)

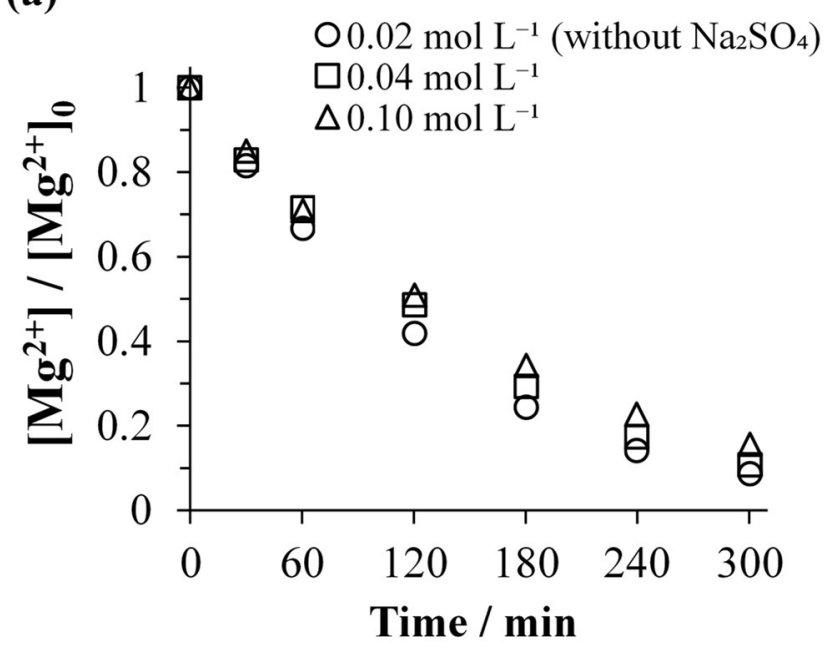

(b)

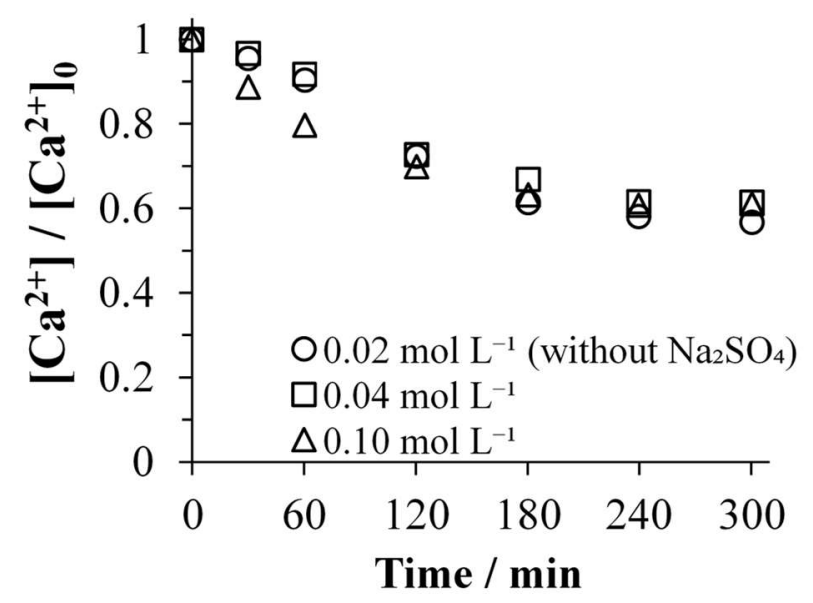

(c)

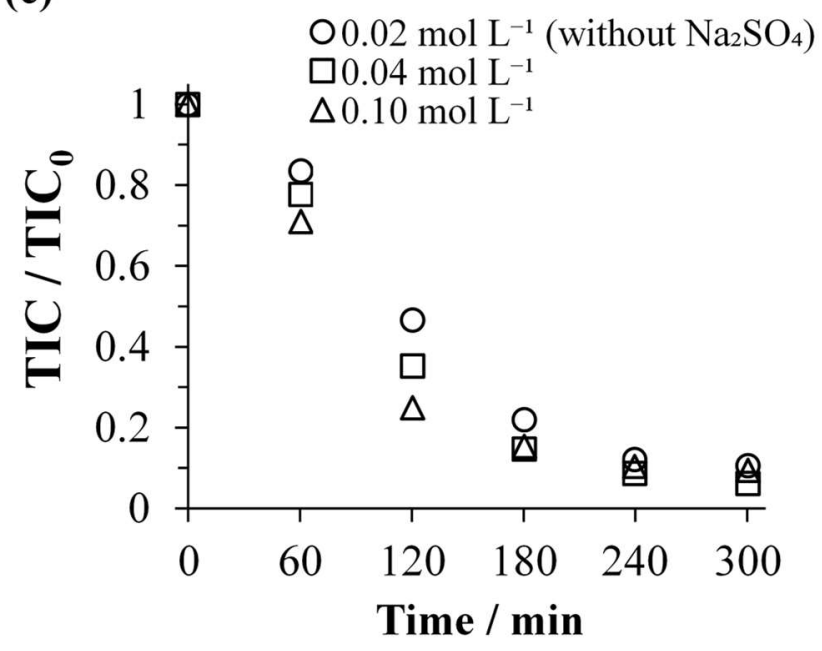

479 Fig. 3. Evolution of concentration of (a) $\mathrm{Mg}^{2+}$, (b) $\mathrm{Ca}^{2+}$ and (c) TIC during the electrolysis of 480 artificial effluents bearing different ionic strengths of $0.02(0)$ (without the addition of supporting 481 electrolyte), $0.04(\square)$ and $0.10(\triangle) \mathrm{mol} \mathrm{L}^{-1}$. Anode: BDD, cathode: stainless steel, applied current density: $4 \mathrm{~mA} \mathrm{~cm}^{-2}$ and inter-electrode distance: $500 \mu \mathrm{m}$. 


\subsection{Influence of matrix of electrolyte}

\subsubsection{Influence of $\mathrm{CO}_{3}{ }^{2-}$ towards the mineral electro-precipitation}

Electrolysis of electrolyte containing $\mathrm{Mg}^{2+}$ and $\mathrm{Ca}^{2+}$, in presence and absence of $\mathrm{CO}_{3}{ }^{2-}$, in the microfluidic flow-by reactor were carried out by applying 0.4 and $4 \mathrm{~mA} \mathrm{~cm}^{-2}$ and the results are plotted in Fig. 4 and Fig. 5. From Fig. 4, it could firstly be observed that $\mathrm{Ca}^{2+}$ did not precipitate in the electrolyte without carbonate at both current densities. It precipitated only in presence of carbonate. Thus, it has been concluded that $\mathrm{Ca}(\mathrm{OH})_{2}$ was not produced throughout these series of experiment and $\mathrm{Ca}^{2+}$ only electro-precipitated to form $\mathrm{CaCO}_{3}$. This observation can be supported by the value of thermodynamic constant of solubility of $\mathrm{Ca}(\mathrm{OH})_{2}$ that is high $\left(5.00 \times 10^{-6}[39,40]\right)$ - thus highly soluble -, hence the interfacial $\mathrm{pH}$ never reached the $\mathrm{OH}^{-}$crit $\left(\right.$i.e. $\left.36.6 \mathrm{~mol} \mathrm{~m}^{-3}, \mathrm{pH}=12.6\right)$ to precipitate with $\mathrm{Ca}^{2+}$. Secondly, according to Fig. 5, $\mathrm{Mg}^{2+}$ only precipitated at $4 \mathrm{~mA} \mathrm{~cm}^{-2}$ and no $\mathrm{Mg}^{2+}$-based deposition occurred at $0.4 \mathrm{~mA} \mathrm{~cm}{ }^{-2}$. At low current density, since no decrease of $\mathrm{Mg}^{2+}$ was observed, it can be concluded that $\mathrm{Mg}(\mathrm{OH})_{2}$ was not electro-precipitated. Same remark was given by Deslouis et al. [30] where they did not observe precipitation of $\mathrm{Mg}(\mathrm{OH})_{2}$ when interfacial $\mathrm{pH}$ of 9.3 was not yet reached. Our result tells that there was a plateau at $4 \mathrm{~mA} \mathrm{~cm}^{-2}$ at the very beginning of electrolysis up to $7 \mathrm{~min}$ before $\mathrm{Mg}^{2+}$ started to deposit forming $\mathrm{Mg}(\mathrm{OH})_{2}$, as soon as $\mathrm{OH}_{\text {crit }}^{-}(0.16$ mol m${ }^{-3}$, interfacial $\left.\mathrm{pH}=10.2\right)$ was reached (Fig. 5). Then, during the first hour of electrolysis at 4 $\mathrm{mA} \mathrm{cm}{ }^{-2}$, a slightly higher kinetics of $\mathrm{Mg}(\mathrm{OH})_{2}$ deposition was observed in the electrolyte without carbonate. In the presence of $\mathrm{CO}_{3}{ }^{2-}$, there was perhaps a weak competition between $\mathrm{Mg}(\mathrm{OH})_{2}$ and $\mathrm{CaCO}_{3}$ for active site on the surface of cathode $[36,70]$. However, it was not accounted for $\mathrm{MgCO}_{3}$, otherwise the kinetics of precipitation with the electrolyte containing $\mathrm{CO}_{3}{ }^{2-}$ would be faster and not slower than the one without $\mathrm{CO}_{3}{ }^{2-}$. To conclude, $\mathrm{Mg}^{2+}$ electro-precipitated independently with regard to carbonate ions.

Moreover, it can be seen in Fig. 4 that $\mathrm{CaCO}_{3}$ was already deposited at low current density, unlike $\mathrm{Mg}(\mathrm{OH})_{2}$ even though the thermodynamic constant of solubility of $\mathrm{Mg}(\mathrm{OH})_{2}$ is lower than that of 
$\mathrm{CaCO}_{3}$. Similar observation was reported by Okstad et al. [71]. The higher initial concentration of

$509 \mathrm{Ca}^{2+}-$ implemented to simulate the composition of reclaimed wastewater from urban WWTPs - can be one of the reasons of this observation, whereby supersaturation degree was already high. On top of that, experimental results showed that $7.2 \%$ more $\mathrm{CaCO}_{3}$ deposition occurred at $0.4 \mathrm{~mA} \mathrm{~cm}^{-2}$ in comparison to higher applied current density of $4 \mathrm{~mA} \mathrm{~cm}{ }^{-2}$. To our understanding, once $\mathrm{CaCO}_{3}$ electro-precipitation started to occur, it took place regardless of applied current density as long as the current density was equal or higher than the starting point of the nucleation of $\mathrm{CaCO}_{3}$ crystal. In case of low and high applied current densities investigated in this work, $\mathrm{CaCO}_{3}$ already formed at the low current density $\left(0.4 \mathrm{~mA} \mathrm{~cm}^{-2}\right)$. It would behave similarly at higher applied current density except that within the latter, oxidation and reduction of solvent on the surface of electrodes were occurring at higher rates leading to higher amount of electro-generated gas. Given the fact that at $0.4 \mathrm{~mA} \mathrm{~cm}^{-2}$ it was already exceeding the limiting current density $\left(0.25 \mathrm{~mA} \mathrm{~cm} \mathrm{~cm}^{-2}\right.$, see section 4.3$)$, gas production was therefore occurring at both applied conditions. It means that the influence of gas evolution was taking place concomitantly with the electro-precipitation on cathode surface [72], but in an antagonist way according to the level of gas production. At $0.4 \mathrm{~mA} \mathrm{~cm}{ }^{-2}$, the lower evolution of gas on the surface of electrode could enhance the mass transfer of reactive towards the electrodes [73-76]. This enhancement would be attributed to firstly micro-convection, even at small value of current density [73], due to evolving and departing gas bubbles from the electrode surface. Secondly, forced convection or macro-convection owing to movement and displacement of bubbles over the electrode surface could also occur [74-76]. Therefore, transport of $\mathrm{Ca}^{2+}$ and $\mathrm{Mg}^{2+}$ towards cathode surface for precipitation reaction were enhanced at the low current density condition. This could explain why slightly more $\mathrm{CaCO}_{3}$ was obtained at lower current density. Contrastingly, higher intensity of gas evolution is expected over the surface of cathode at high applied current density $\left(4 \mathrm{~mA} \mathrm{~cm}^{-2}\right)$. Therefore, bubble coverage at the electrode surface should have increased as described by Vogt et al. [41]. Therefore, the more intense gas evolution at higher applied current density could have disturbed 
the layer of $\mathrm{CaCO}_{3}$ nuclei and in-parallel promoted the detachment of $\mathrm{CaCO}_{3}$ deposit $[\mathbf{4 2}, \mathbf{4 3}, \mathbf{6 2}]$. Consequently, less electro-precipitation of $\mathrm{CaCO}_{3}$ was observed at higher applied current density.

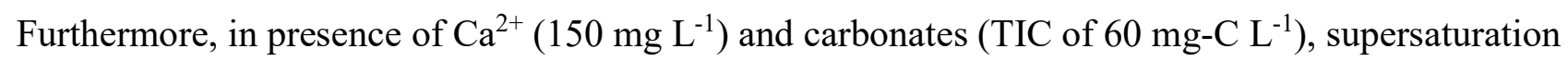
index (SI) defined in Eq. (15) equaled to 0.89 in the initial electrolyte. It means that $\mathrm{Ca}^{2+}$ and $\mathrm{CO}_{3}^{2-}$ concentrations in the bulk were already above their equilibrium state in water (where SI $=0$ ) initially [49]. From the thermodynamic point of view, $\mathrm{CaCO}_{3}$ precipitation in the bulk and scaling on metal substrate could occur. However, the induction time for homogenous and heterogeneous $\mathrm{CaCO}_{3}$ nucleation varies in function of physico-chemical component of bulk liquid as well as metal substrate $[29,50,77]$. According to Gabrielli et al., thermodynamics requires a 40-fold supersaturation before the precipitation in the bulk can be observed, i.e. equivalent to SI value around $1.6[\mathbf{1 8 , 7 7 , 7 8 ]}$. It has also been demonstrated that under low supersaturation conditions, very long induction time (12 h) was required before observing scaling on metal substrate [79]. This might be one of the reasons sluggish kinetics of electro-precipitation of $\mathrm{CaCO}_{3}$ was observed at the very beginning of electrolysis in Fig. 4. With respect to the evolution of experimental TIC concentrations (Fig. S2 (a-d)) as well as to the modeled interfacial $\mathrm{CO}_{3}{ }^{2-}$ concentrations illustrated in Fig. 6, this slow initial kinetics were also noticed. From Fig. 6, it can be noticed that on cathode surface, $\mathrm{CO}_{3}{ }^{2-}$ departed from its initial bulk concentration and rapidly increased owing to electrogenerated $\mathrm{OH}^{-}$once the electrolysis started. With increasing quantity of interfacial $\mathrm{CO}_{3}{ }^{2-}$, more $\mathrm{CO}_{3}{ }^{2-}$ was readily available to react with $\mathrm{Ca}^{2+}$ to form $\mathrm{CaCO}_{3}$ scaling. The supersaturation degree quickly increased, thus promoting the deposition of $\mathrm{CaCO}_{3}$. The concentration of interfacial $\mathrm{CO}_{3}{ }^{2-} \mathrm{kept}$ increasing as long as the rate of production of $\mathrm{OH}^{-}$was superior to the rate of production of $\mathrm{CaCO}_{3}$ (or $\mathrm{CO}_{3}{ }^{2-}$ consumption at the interface). During this period, more $\mathrm{CO}_{3}{ }^{2-}$ was shifted from $\mathrm{HCO}_{3}{ }^{-}$form since the $\mathrm{OH}^{-}$concentration also increased, the phenomenon that contributed towards local alkalization. A peak was attained when the rate of $\mathrm{OH}^{-}$ production equaled that of $\mathrm{CO}_{3}{ }^{2-}$ consumed. Beyond this peak, the rate of electro-precipitation of $\mathrm{CaCO}_{3}$ declined due to decreasing concentration of both $\mathrm{Ca}^{2+}$ and $\mathrm{CO}_{3}{ }^{2-}$ in the electrolyte at later stage of electrolysis as can be observed in Fig. 4. When comparing the evolution of interfacial $\mathrm{CO}_{3}{ }^{2-}$ 
559 concentration modeled at $4 \mathrm{~mA} \mathrm{~cm}^{-2}$ (Fig. 6(a)) against $0.4 \mathrm{~mA} \mathrm{~cm}{ }^{-2}$ (Fig. 6(b)), three remarks can 560 be made; firstly, longer time was needed to reach the peak at $r_{\mathrm{OH}^{-}}=r_{\mathrm{CaCO}_{3}}$. Secondly, smaller 561 concentration of interfacial $\mathrm{CO}_{3}{ }^{2-}$ was produced at higher current density and thirdly, $\mathrm{CaCO}_{3}$ electro562 precipitation occurred at relatively slower rate after the peak of equivalence. The involvement of gas 563 evolution might explain the described behaviors. As above-mentioned, intensified evolving $\mathrm{H}_{2}$ gas 564 on cathode surface at higher applied current density decreased significantly the effective surface area 565 of cathode even though the $\mathrm{OH}^{-}$production was enhanced in the meantime. Consequently, longer 566 buffer time was observed in Fig. 4(a) (inset curve) at the beginning of electrolysis in comparison to 567 Fig. 4(b). Lesser amount of interfacial $\mathrm{CO}_{3}{ }^{2-}$ was also expected at the proximity of cathode surface 568 due to the intervention of evolving gas. This disturbance on cathode took place throughout the 569 electrolysis and consequently, plausible detachment of $\mathrm{CaCO}_{3}$ scaling occurred along the way. In 570 overall, slower kinetics of $\mathrm{CaCO}_{3}$ deposition was observed under high current density, affirmed by 571 the trend depicted in Fig. 4. 
(a)

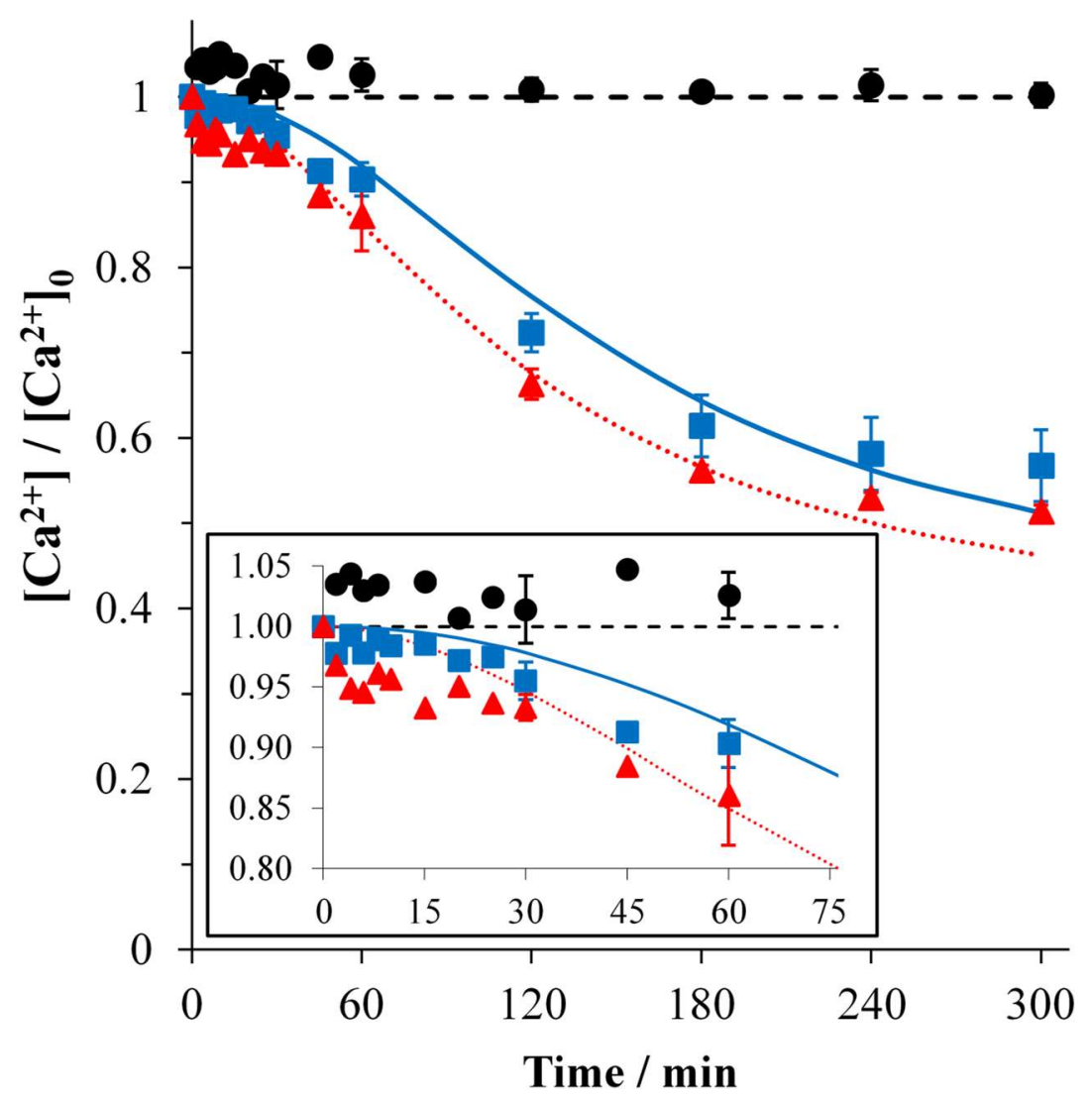

(b)

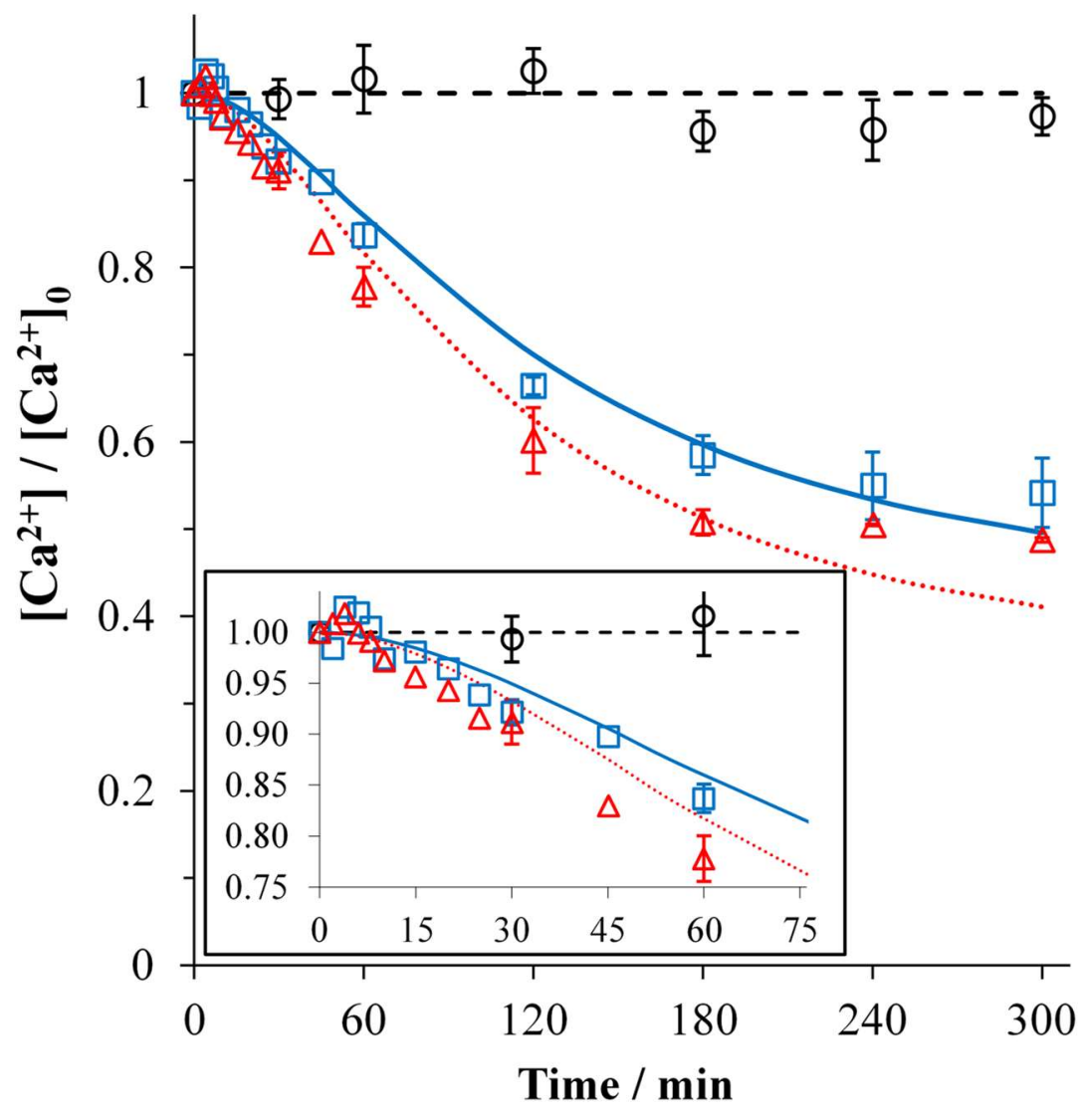


573 Fig. 4. Evolution of concentration of $\mathrm{Ca}^{2+}$ during the electrolysis of different matrices of electrolyte $574\left(\bullet, \circ: \mathrm{Ca}^{2+}\right.$ and $\mathrm{Mg}^{2+}$ without $\mathrm{CO}_{3}{ }^{2-}$, ㄸ, $\square: \mathrm{Ca}^{2+}, \mathrm{Mg}^{2+}$ and $\mathrm{CO}_{3}{ }^{2-}$ and $\Delta, \triangle: \mathrm{Ca}^{2+}$ and $\mathrm{CO}_{3}{ }^{2-}$ without $\left.575 \mathrm{Mg}^{2+}\right)$ at (a) $4 \mathrm{~mA} \mathrm{~cm}^{-2}(\bullet, \mathbf{\square}, \mathbf{\Delta})$ and (b) $0.4 \mathrm{~mA} \mathrm{~cm}^{-2}(\circ, \square, \Delta)$ applied current density. (- - -): 576 model curve for $\mathrm{Ca}^{2+}$ and $\mathrm{Mg}^{2+}$ electrolyte without $\mathrm{CO}_{3}{ }^{2-},(-)$ : model curve for $\mathrm{Ca}^{2+}, \mathrm{Mg}^{2+}$ and $577 \mathrm{CO}_{3}{ }^{2-}$ electrolyte and (........): model curve for $\mathrm{Ca}^{2+}$ and $\mathrm{CO}_{3}{ }^{2-}$ without $\mathrm{Mg}^{2+}$ electrolyte. Inset: 578 zoom of the initial kinetic evolution of $\mathrm{Ca}^{2+}$. Anode: BDD, cathode: stainless steel and interelectrode distance: $500 \mu \mathrm{m}$. 
(a)

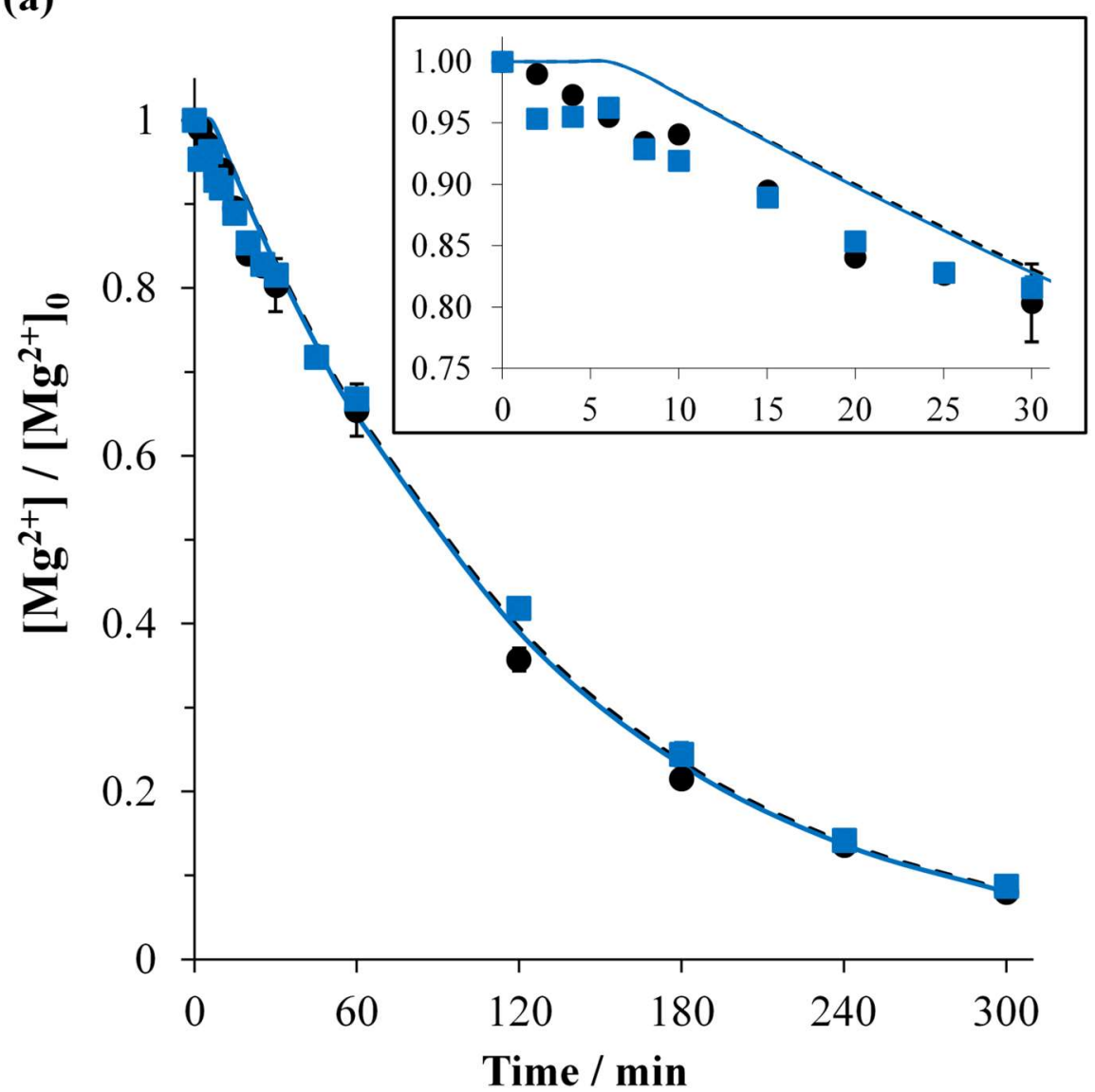

(b)

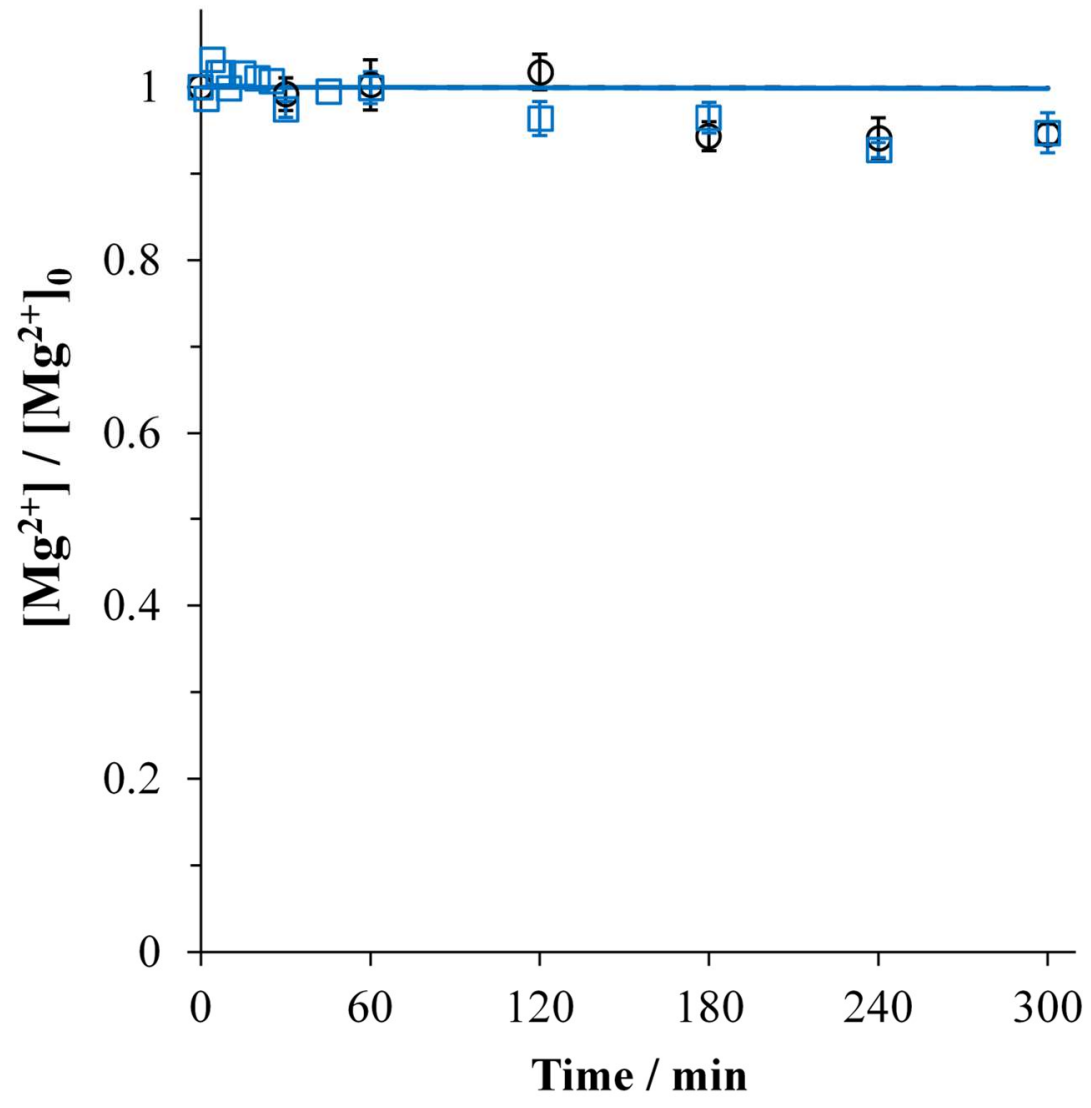


(a)

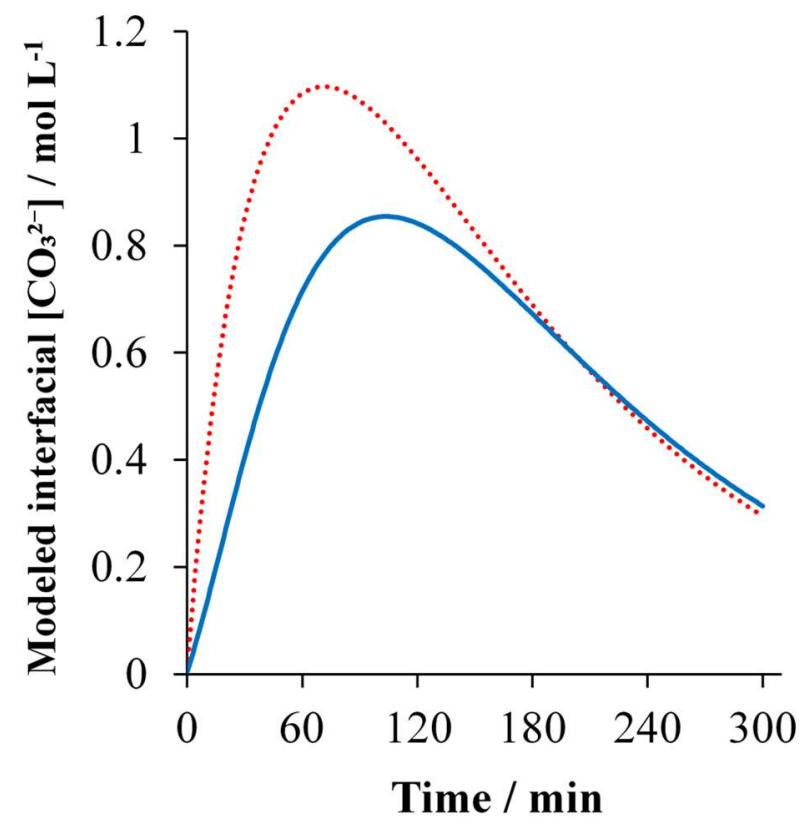

(b)

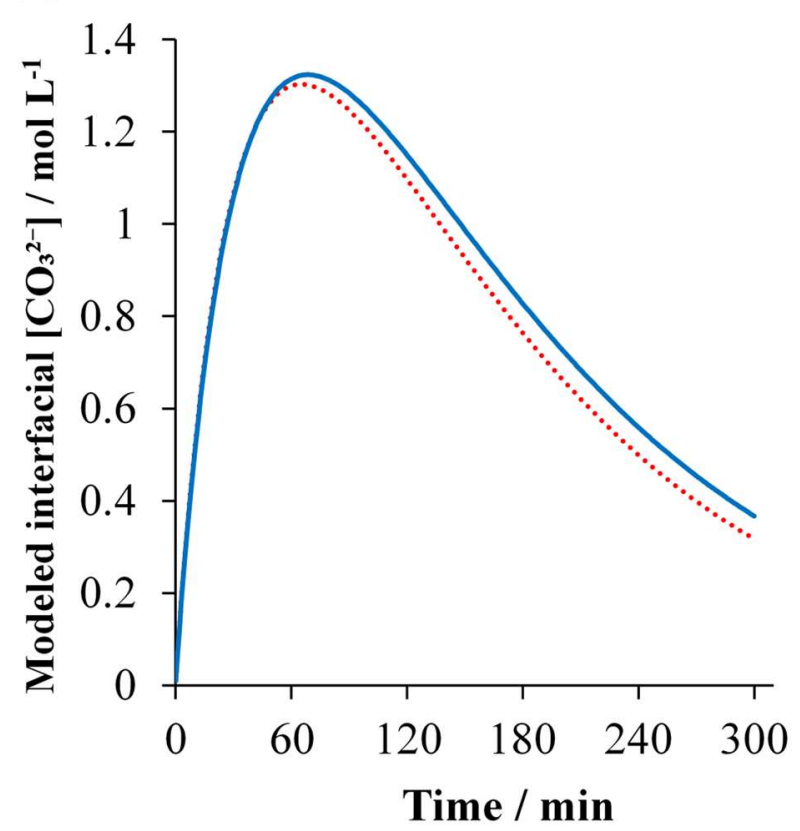

Fig. 5. Evolution of concentration of $\mathrm{Mg}^{2+}$ during the electrolysis of different matrices of electrolyte $\left(\bullet, \circ: \mathrm{Ca}^{2+}\right.$ and $\mathrm{Mg}^{2+}$ without $\mathrm{CO}_{3}{ }^{2-}$ and $\mathbf{\bullet}, \square: \mathrm{Ca}^{2+}, \mathrm{Mg}^{2+}$ and $\left.\mathrm{CO}_{3}{ }^{2-}\right)$ at (a) $4 \mathrm{~mA} \mathrm{~cm}{ }^{-2}(\bullet, \square)$ and (b) $0.4 \mathrm{~mA} \mathrm{~cm}{ }^{-2}(\circ, \square)$ applied current density. (- - -): model curve for $\mathrm{Ca}^{2+}$ and $\mathrm{Mg}^{2+}$ electrolyte without $\mathrm{CO}_{3}{ }^{2-}$ and $(-)$ : model curve for $\mathrm{Ca}^{2+}, \mathrm{Mg}^{2+}$ and $\mathrm{CO}_{3}{ }^{2-}$ electrolyte. Inset: zoom of the initial kinetic evolution of $\mathrm{Mg}^{2+}$. Anode: BDD, cathode: stainless steel and inter-electrode distance: $500 \mu \mathrm{m}$.

Fig. 6. Modeled concentration of interfacial $\mathrm{CO}_{3}{ }^{2-}$ during the electrolysis of electrolyte containing $\mathrm{Ca}^{2+}, \mathrm{Mg}^{2+}$ and $\mathrm{CO}_{3}{ }^{2-}(-)$ and electrolyte containing: $\mathrm{Ca}^{2+}$ and $\mathrm{CO}_{3}{ }^{2-}$ without $\mathrm{Mg}^{2+}(\ldots \ldots \ldots)$ under the polarization of (a) $4 \mathrm{~mA} \mathrm{~cm}^{-2}$ and (b) $0.4 \mathrm{~mA} \mathrm{~cm}^{-2}$ applied current density. Anode: BDD, cathode: stainless steel and inter-electrode distance: $500 \mu \mathrm{m}$.

\subsubsection{Influence of $\mathrm{Mg}^{2+}$ towards the mineral electro-precipitation}

To investigate the role of $\mathrm{Mg}^{2+}$ towards $\mathrm{CaCO}_{3}$ deposition in microfluidic reactor, two electrolytes, both consisting of $\mathrm{Ca}^{2+}$ and $\mathrm{CO}_{3}{ }^{2-}$ but only one contained $\mathrm{Mg}^{2+}$, were compared. According to Fig. 4, at both applied current densities, concentrations of $\mathrm{Ca}^{2+}$ decreased over time. In both cases, higher degree of $\mathrm{CaCO}_{3}$ electro-precipitation (12\%) was observed in the system in absence of $\mathrm{Mg}^{2+}$. This 
difference was even more significant when the electrochemical cell was polarized with lower current density where the interface was less perturbed by evolving gas (Fig. 4(b)). This finding can be attributed to the inhibition effect of $\mathrm{Mg}^{2+}$ during $\mathrm{CaCO}_{3}$ deposition $[25, \mathbf{3 0}, \mathbf{3 4}, \mathbf{4 2}, \mathbf{4 9}] . \mathrm{Mg}^{2+}$ can either incorporate into the $\mathrm{CaCO}_{3}$ lattices lowering their growth kinetics on cathode surface $[25,49$, 80], or, a thin layer of magnesian gel-like film $[42,70,81]$ - which was formed prior to the $\mathrm{CaCO}_{3}$ deposition $[37,81]$ - partially limited the surface reactivity of cathode towards the scaling of $\mathrm{CaCO}_{3}$. Nonetheless, it has been reported that $\mathrm{CaCO}_{3}$ crystal can still develop and grow on the layer of $\mathrm{Mg}(\mathrm{OH})_{2}$ as confirmed by mixture of brucite and aragonite crystals from microscopic techniques [42, 81-83]. With regard to the competing reaction of gas evolution on the surface of cathode at higher current density, it remained true while working with electrolyte without $\mathrm{Mg}^{2+}$. More intense $\mathrm{H}_{2}$ gas evolution led to less $\mathrm{CaCO}_{3}$ electro-precipitation (Fig. 4) as previously described. A slight difference was found in terms of $\mathrm{CaCO}_{3}$ crystallography according to literature. When cathode potential was relatively low in the region of solvent reduction, $\mathrm{CaCO}_{3}$ deposit has been reported to crystallize under cubic calcite allotropy. Whilst in presence of $\mathrm{Mg}^{2+}, \mathrm{CaCO}_{3}$ takes aragonite form $[\mathbf{1 8 , 2 3 , 3 7 , 4 2 , 6 2 ]}$. Under strong evolving gas activity, porous structure of $\mathrm{CaCO}_{3}$ deposit has been reported [35-37, 43, 84].

In addition, the trends of modeled interfacial $\mathrm{CO}_{3}{ }^{2-}$ depicted on Fig. 6 complement the deduction made on the inhibiting role of $\mathrm{Mg}^{2+}$ towards $\mathrm{CaCO}_{3}$ electro-precipitation. At higher applied current density (4 mA cm${ }^{-2}$, Fig. 6(a)), $\mathrm{Mg}(\mathrm{OH})_{2}$ deposit was formed in the electrolyte containing $\mathrm{Mg}^{2+}$. The formation of $\mathrm{Mg}(\mathrm{OH})_{2}$ deposit partly consumed interfacial $\mathrm{OH}^{-}$. As a result, $r_{\mathrm{OH}^{-}}$decreased as accounted in the model (Eq. (23)). Together with $\mathrm{H}_{2}$ gas evolution at higher current polarization, the increment of interfacial $\mathrm{CO}_{3}{ }^{2-}$ concentration was slower in the electrolyte in presence of $\mathrm{Mg}^{2+}$ relatively to the one without $\mathrm{Mg}^{2+}$. Smaller interfacial $\mathrm{CO}_{3}{ }^{2-}$ concentration was expected at cathode surface therefore lowering kinetic rate of $\mathrm{CaCO}_{3}$ electro-precipitation. Contrastingly, $\mathrm{Mg}(\mathrm{OH})_{2}$ electro-precipitation did not take place at lower current density. Gas evolution was significantly lower at $0.4 \mathrm{~mA} \mathrm{~cm}^{-2}$. Consequently, the evolution of modeled interfacial $\mathrm{CO}_{3}{ }^{2-}$ concentrations (Fig. 6(b)) 
623 for both electrolytes in absence and presence of $\mathrm{Mg}^{2+}$ were quite similar. It means that the availability 624 of interfacial $\mathrm{CO}_{3}{ }^{2-}$ on cathode surface was about the same for either electrolyte. Hence, it was then 625 confirmed from Fig. 4(b) that the lower growth rate of $\mathrm{CaCO}_{3}$ deposition obtained in the presence of $626 \mathrm{Mg}^{2+}$ at lower current density was due to the decrease of supersaturation degree of $\mathrm{CaCO}_{3}$ in the 627 presence of $\mathrm{Mg}^{2+}$ [85]. As previously discussed, it can adsorb or incorporate into $\mathrm{CaCO}_{3}$ crystal lattice 628 inhibiting its growth during the electrolysis $[49,80]$.

\subsubsection{Influence of $\mathrm{Ca}^{2+}$ towards the mineral electro-precipitation}

630

Fig. 7 illustrates the behavior of mineral deposition during electrolysis in the presence or absence of $\mathrm{Ca}^{2+}$ at 4 and $0.4 \mathrm{~mA} \mathrm{~cm}^{-2}$. From Fig. 7(a), it was observed that $\mathrm{Mg}^{2+}$ underwent electro-precipitation independently of $\mathrm{Ca}^{2+}$. The evolution of concentration of $\mathrm{Mg}^{2+}$ in presence of $\mathrm{Ca}^{2+}$ followed exactly the trend given in absence of $\mathrm{Ca}^{2+}$. This observation indicated indifferent role of $\mathrm{Ca}^{2+}$ towards the deposition of $\mathrm{Mg}^{2+}$. From Fig. 7(b), it was noticed that $\mathrm{Mg}^{2+}$ did not precipitate at lower applied current density $\left(0.4 \mathrm{~mA} \mathrm{~cm}^{-2}\right)$ in both matrices of electrolyte. The evolution of TIC in Fig. S2(e-f) suggested that the concentration of $\mathrm{CO}_{3}{ }^{2-}$ declined negligibly over time in the matrix without $\mathrm{Ca}^{2+}$ relatively to the behavior in the presence of $\mathrm{Ca}^{2+}$. This tendency coupled with the observation made in Fig. 7(a) allowed deducing on the absence of electro-precipitation of $\mathrm{MgCO}_{3}$ in our operated microfluidic cell configuration. In addition, considering the fact that $\mathrm{CO}_{3}{ }^{2-}$ did not precipitate in the absence of $\mathrm{Ca}^{2+}$, the results in this section corroborated with those in section 4.4.1 in which $\mathrm{CO}_{3}^{2-}$ only underwent precipitation with $\mathrm{Ca}^{2+}$ to form $\mathrm{CaCO}_{3}$ deposit. The evolution of modeled interfacial $\mathrm{CO}_{3}{ }^{2-}$ concentration in the case without $\mathrm{Ca}^{2+}$ plotted in Figs. 7(c) and 7(d) might as well come into similar conclusion. Interfacial $\mathrm{CO}_{3}{ }^{2-}$ concentration increased in conjunction to $\mathrm{OH}^{-}$production on electrode surface. No $\mathrm{CO}_{3}{ }^{2-}$ was consumed at the vicinity of cathode in the absence of $\mathrm{Ca}^{2+}$ allowing a continuous and quicker shift into $\mathrm{CO}_{3}{ }^{2-}$ form at cathode interface. The interfacial $\mathrm{CO}_{3}{ }^{2-}$ concentration arrived at a quasi-plateau at the end of electrolysis when the majority of carbon was 
647 converted into $\mathrm{CO}_{3}{ }^{2-}$ form. Slower rate of $\mathrm{OH}^{-}$production at higher applied current was due to 648 involvement of $\mathrm{H}_{2}$ evolution activity.

649 To summarize, $\mathrm{Mg}^{2+}$ deposited under the form of $\mathrm{Mg}(\mathrm{OH})_{2}$ and it was not influenced by the presence 650 of $\mathrm{Ca}^{2+}$ nor $\mathrm{CO}_{3}{ }^{2-}$. Only applied current density influenced the electro-precipitation of $\mathrm{Mg}(\mathrm{OH})_{2}$ as 651 already described in section 4.4.1. According to Bénézeth et al. [52], $\mathrm{MgCO}_{3}$ or commonly known as 652 magnesite, possesses very slow kinetics of crystallization. Other hydrated Mg-carbonates forms are 653 plausible owing to slow precipitation kinetics of the former, but they are rather unstable due to strong 654 hydrated character of $\mathrm{Mg}^{2+}[\mathbf{5 2}, \mathbf{8 6}, \mathbf{8 7}]$. As a result, direct electro-precipitation of $\mathrm{MgCO}_{3}$ would be 655 realizable but only under stringent conditions, i.e. elevated departing supersaturated solution, elevated 656 temperature and very high $\mathrm{CO}_{2}$ partial pressure [88]. Hence, based on our experimental results 657 supported by the work of other authors, $\mathrm{MgCO}_{3}$ was not formed under our experimental conditions. 

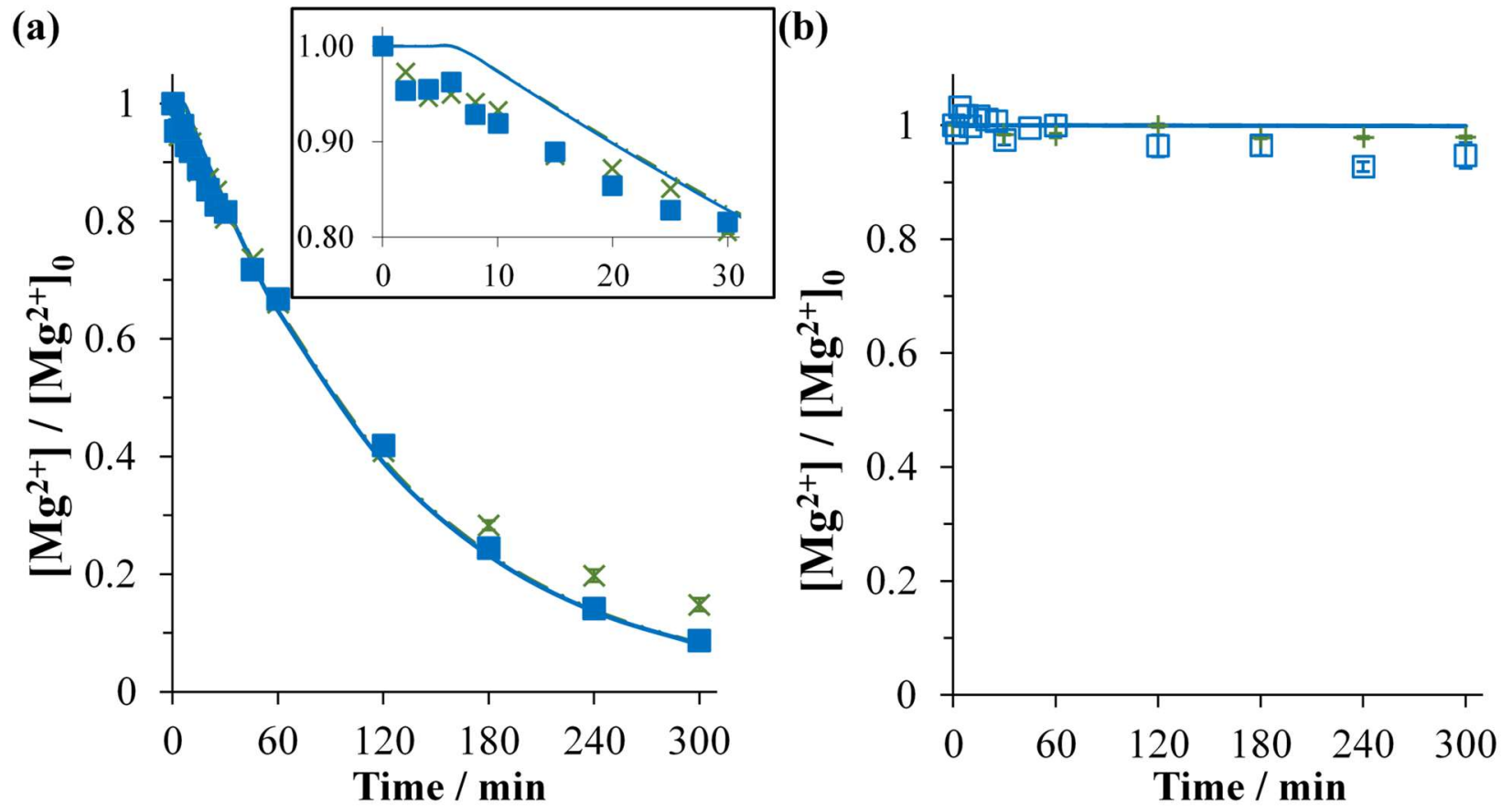

(c)

(d)

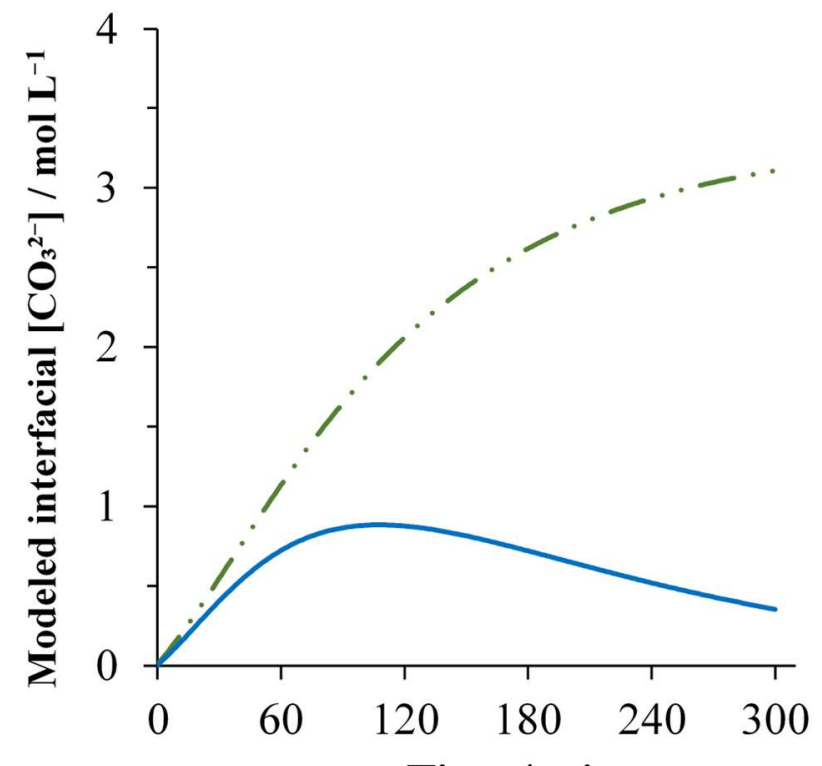

Time / min

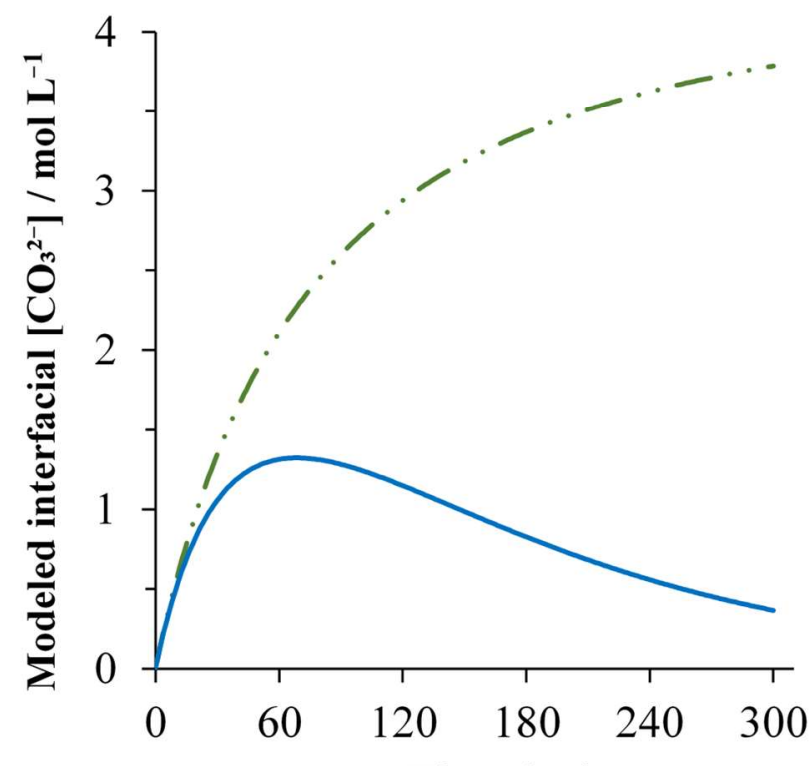

Time / min

659 Fig. 7. Evolution of $\mathrm{Mg}^{2+}(\mathbf{a}, \mathbf{b})$ and modeled interfacial $\mathrm{CO}_{3}{ }^{2-}(\mathbf{c}, \mathbf{d})$ concentrations during the 660 electrolysis of electrolyte containing $\mathrm{Ca}^{2+}(\mathbf{\square}, \square)$ or without $\mathrm{Ca}^{2+}(\times,+)$ at $4 \mathrm{~mA} \mathrm{~cm}(\mathbf{a}, \mathbf{c})$ and 0.4 $661 \mathrm{~mA} \mathrm{~cm}^{-2}(\mathbf{b}, \mathbf{d})$. Model curves of electrolyte in presence of $\mathrm{Ca}^{2+}(-)$ or in absence of $\mathrm{Ca}^{2+}($ $662-\cdots)$. Inset (a): zoom of the initial kinetics evolution of $\mathrm{Mg}^{2+}$. Anode: BDD, cathode: stainless 663 steel and inter-electrode distance: $500 \mu \mathrm{m}$. 


\subsubsection{Evolution of $\mathrm{pH}$ and conductivity}

In Fig. S3 are plotted the graphs of variation of bulk solution $\mathrm{pH}$ and ionic conductivity throughout the electrolysis of all investigated matrices of electrolyte at both high and low applied current densities. Few general trends can be drawn from these curves. Firstly, solution $\mathrm{pH}$ and ionic conductivity tended to decrease in the bulk during the electro-precipitation process. The decrease in $\mathrm{pH}$ was the most remarkable in the electrolyte without carbonates since no buffer effect of $\mathrm{HCO}_{3}{ }^{-}$ $/ \mathrm{CO}_{3}{ }^{2-}$ was present in this matrix. Similar remark was also made by other authors, Tlili et al. [64] and Piri et al. [43], when they checked upon the variation of $\mathrm{pH}$ in bulk solution during the formation of $\mathrm{CaCO}_{3}$. This drop of $\mathrm{pH}$ value was ascribed to the consumption of $\mathrm{OH}^{-}$that partake in the reaction of $\mathrm{Mg}(\mathrm{OH})_{2}$ deposition according to Eq. (3). It could also be attributed to the $\mathrm{pH}$ participation towards the thermodynamic equilibrium shift of $\mathrm{HCO}_{3}{ }^{-} / \mathrm{CO}_{3}{ }^{2-}$ in favor of $\mathrm{CO}_{3}{ }^{2-}$ formation in Eq. (5), while consuming $\mathrm{OH}^{-}$. Net concentration of $\mathrm{OH}^{-}$in the bulk therefore declined, indicated by the decrease of measured bulk $\mathrm{pH}$. The only case where bulk $\mathrm{pH}$ did not decrease was during the electrolysis of electrolyte in absence of $\mathrm{Ca}^{2+}$. At both applied current densities, $\mathrm{CaCO}_{3}$ deposit was not formed. Meanwhile, $\mathrm{OH}^{-}$was continuously electro-generated on the surface of cathode. $\mathrm{OH}^{-}$diffusing from cathode surface to the bulk only reacted with existing $\mathrm{HCO}_{3}{ }^{-}$until complete conversion into the basic form, i.e. $\mathrm{CO}_{3}{ }^{2-}$ (Eq. (5)). Then, the accumulation of $\mathrm{OH}^{-}$in the bulk yielded in an increase of $\mathrm{pH}$ value. Moreover, the only electro-precipitation that occurred in the electrolyte in absence of $\mathrm{Ca}^{2+}$ was $\mathrm{Mg}(\mathrm{OH})_{2}$ and it was only seen at higher range of applied current density. However, as demonstrated in Fig. S3(a), $\mathrm{OH}^{-}$consumed for the deposition of $\mathrm{Mg}(\mathrm{OH})_{2}$ on cathode surface contributed trivially towards the diminishing pattern of $\mathrm{pH}$ in the bulk unlike during the deposition of $\mathrm{CaCO}_{3}$.

Similar argument can be done towards the trend of ionic conductivity in the bulk. Knowing the fact that $\mathrm{OH}^{-}$possesses high value of ionic conductivity despite not being the highest relatively to $\mathrm{H}^{+}$, its consumption throughout the electro-precipitation event of $\mathrm{CaCO}_{3}$ manifested a decline in overall bulk ionic conductivity as shown in Fig. S3(c) and Fig. S3(d). 


\subsubsection{Mass balance and elements recovery}

691 Fig. 8 depicts the recovery of $\mathrm{Mg}$ and $\mathrm{Ca}$ from the different electrochemical reactor compartments at 692 the end of experiment for different matrices of electrolyte at both current densities investigated. Very 693 high percentage of $\mathrm{Mg}$ and $\mathrm{Ca}$ recovery across all experiments was verified with the lowest being $69490 \%$. The percentage of recovery across all electrolysis took an average value of 95\%. From Fig. 8, 695 in the case where electro-precipitation occurred, high percentage of $\mathrm{Mg}$ and $\mathrm{Ca}$ were recovered from 696 cathode while negligible quantity was found in tubing and from anode surface. It is important to note 697 that high $\mathrm{Mg}$ and Ca recovery means negligible loss of the elements was ensured. Mass balance of $698 \mathrm{Mg}$ and $\mathrm{Ca}$ from different compartment was conserved. Consequently, the trends of cation 699 concentrations depicted in previous figures were reliable. Their decay from electrolyte bulk, coupled 700 to high mass recovery from cathode surface was indicative of mineral precipitations occurring on the 701 cathode.

702 Looking at Fig. 8(b), percentages of mass of $\mathrm{Ca}$ recovered from cathode in both matrices of 703 electrolyte were higher at $0.4 \mathrm{~mA} \mathrm{~cm}^{-2}$ as compared to $4 \mathrm{~mA} \mathrm{~cm}{ }^{-2}$, confirming the relative influence 704 of evolving gas activity on cathode surface. Moreover, the percentage of Ca recovery from cathode 705 was always lower in the matrix in presence of $\mathrm{Mg}^{2+}$, whatever the current density applied. It is in 706 agreement with the fact that less $\mathrm{Ca}^{2+}$ was electro-precipitated in presence of $\mathrm{Mg}^{2+}$ demonstrating the 707 inhibition effect of the latter towards $\mathrm{CaCO}_{3}$ co-precipitation with $\mathrm{Mg}(\mathrm{OH})_{2}$.

708 On the other hand, the recovery of $\mathrm{Mg}$ in all electrolytes under study illustrated in Fig. 8(a) confirmed 709 that the $\mathrm{Mg}^{2+}$-based deposit only took place under high current density. It further corroborated the 710 fact that the formation of $\mathrm{Mg}(\mathrm{OH})_{2}$ deposit was not influenced by other ionic species co-present in 711 the electrolyte. 
(a)

712

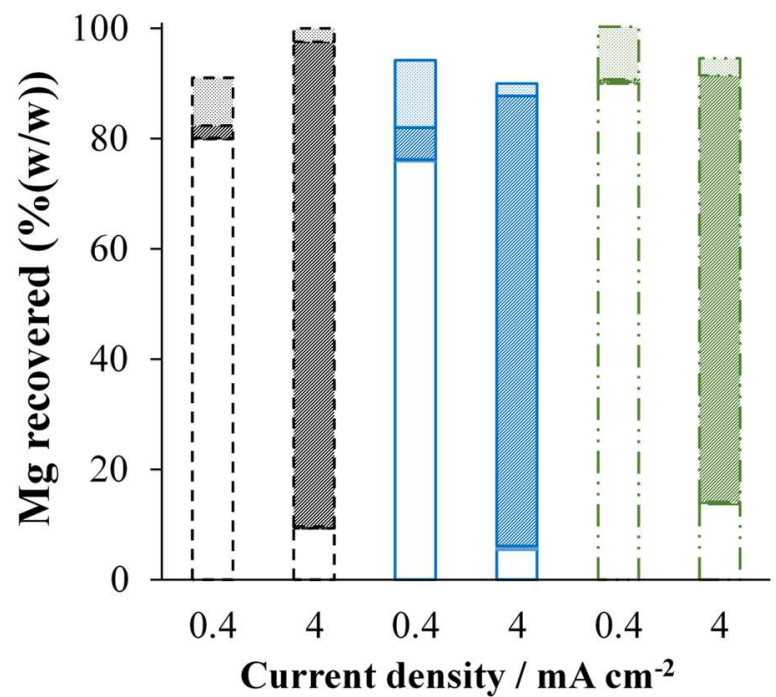

(b)

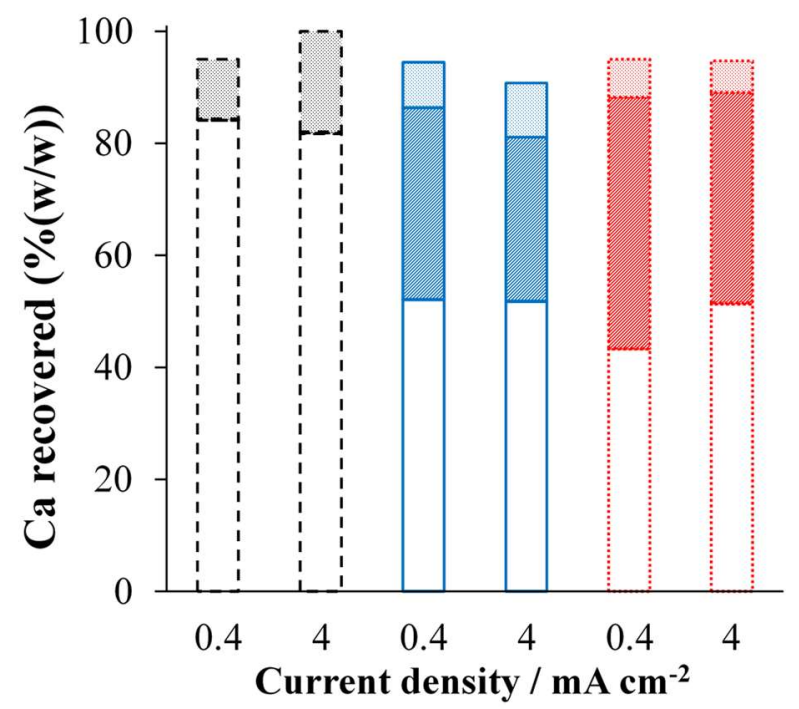

713

714

715

Fig. 8. Percentages (w/w) of (a) Mg and (b) Ca recovered from different parts of experimental pilot ( $\square$ : electrolyte, $\mathbb{Z}$ : cathode, $\boxplus$ : anode and $\otimes:$ tube) after 300 min-electrolysis at 0.4 and $4 \mathrm{~mA} \mathrm{~cm}^{-2}$ of different matrices of electrolyte ((-----): $\mathrm{Ca}^{2+}$ and $\mathrm{Mg}^{2+}$ without $\mathrm{CO}_{3}{ }^{2-},(-)$ : $\mathrm{Ca}^{2+}, \mathrm{Mg}^{2+}$ and $\mathrm{CO}_{3}{ }^{2-},(-\quad)$ : $\mathrm{Ca}^{2+}$ and $\mathrm{CO}_{3}{ }^{2-}$ without $\mathrm{Mg}^{2+}$, and $(-\cdots-\cdots): \mathrm{Mg}^{2+}$ and $\mathrm{CO}_{3}{ }^{2-}$ without $\left.\mathrm{Ca}^{2+}\right)$.

\subsubsection{Theoretical evolution of $\mathrm{Ca}^{2+}, \mathrm{Mg}^{2+}$ and interfacial $\mathrm{CO}_{3}{ }^{2-}$ during electrolysis in different matrices}

Simulations of evolution of $\mathrm{Mg}^{2+}$ concentration during the electrolysis of all matrices of electrolyte depicted in Fig. 5(a), Fig. 5(b), Fig. 7(a) and Fig. 7(b) fitted very well with their corresponding experimental curves. Their RMSE values stayed underneath 0.0078 as summarized in Table S2 whilst ME and IOA values remained above 0.9849 and 0.9956 respectively under all case study. The modelling indicated that under the polarization of $4 \mathrm{~mA} \mathrm{~cm}{ }^{-2}$, it took approximately 7 min for the electrochemical system to reach interfacial $\mathrm{OH}_{\text {crit }}^{-}\left(0.16 \mathrm{~mol} \mathrm{~m}^{-3}\right.$, interfacial $\left.\mathrm{pH}_{\text {crit }}=10.2\right)$ before $\mathrm{Mg}^{2+}$ starting to precipitate. This lag time was also observed experimentally as illustrated in inset of Fig. 5(a) and Fig. 7(a). The model of $\mathrm{Mg}^{2+}$ concentrations decreased over time following the calibrated empirical value of $k_{\mathrm{Mg}(\mathrm{OH})_{2}}$ of $0.330 \mathrm{~m}^{6} \mathrm{~mol}^{-2} \mathrm{~min}^{-1}$. Exactly same trend was observed across all matrices of electrolyte containing $\mathrm{Mg}^{2+}$ since $\mathrm{Mg}(\mathrm{OH})_{2}$ deposition was independent of $\mathrm{CO}_{3}{ }^{2-}$ and $\mathrm{Ca}^{2+}$ 
ions. Accordingly, similar procedures were carried out for $\mathrm{Ca}(\mathrm{OH})_{2}$ deposit. However, due to high solubility of $\mathrm{Ca}(\mathrm{OH})_{2}$, the $\mathrm{OH}_{\text {crit }}^{-}$concentration that needed to be reached was as high as $36.6 \mathrm{~mol} \mathrm{~m}^{-}$ ${ }^{3}(\mathrm{pH}=12.6)$. Under our investigated experimental setup, this $O H_{\text {crit }}^{-}$value was not achieved by either applied current density. Maximum theoretical interfacial $\mathrm{OH}^{-}$concentration was obtained under $4 \mathrm{~mA}$ $\mathrm{cm}^{-2}$ at $7.43 \mathrm{~mol} \mathrm{~m}^{-3}(\mathrm{pH}=11.8)$. As a consequence, no precipitation of $\mathrm{Ca}(\mathrm{OH})_{2}$ was observed.

The modelling of interfacial $\mathrm{CO}_{3}{ }^{2-}$ concentration at cathode surface was rather accurate as extensively discussed in section 4.4.1 to 4.4.3. In agreement to Eq. (20) and Eq. (23), interfacial $\mathrm{CO}_{3}{ }^{2-}$ was proven to be dependent on applied current density; hence $\mathrm{H}_{2}$ gas evolution activity on cathode. Its concentration was as well influenced by the consumption of interfacial $\mathrm{OH}^{-}$. Taking into account these matters, Eq. (21) yields reliable models of evolution of $\mathrm{Ca}^{2+}$ concentration across multiple matrices of electrolyte investigated. The calibrated empirical value of constant rate of $\mathrm{CaCO}_{3}$ electroprecipitation $\left(k_{\mathrm{CaCO}_{3}}\right)$ was $3.6 \times 10^{-3} \mathrm{~m}^{3} \mathrm{~mol}^{-1} \mathrm{~min}^{-1} \cdot \mathrm{Ca}^{2+}$ model curves fitted their experimental counterparts well. In agreement to listed values in Table S2, the lowest RMSE was 0.0761 in the system containing $\mathrm{Mg}^{2+}, \mathrm{Ca}^{2+}$ and $\mathrm{CO}_{3}{ }^{2-}$ at low applied current density. Other RMSE values ranged from 0.0828 to 0.1163 and the $\mathrm{Ca}^{2+}$ model fitting remained reliable in accordance to other model fitting criteria such as ME and IOA. Their respective values obtained for the case with worst RMSE fitting (i.e. matrix containing $\mathrm{Ca}^{2+}$ and $\mathrm{CO}_{3}{ }^{2-}$ without $\mathrm{Mg}^{2+}$ at $0.4 \mathrm{~mA} \mathrm{~cm}{ }^{-2}$ ) were 0.9758 and 0.9934 .

In order to account for intensive concomitant $\mathrm{H}_{2}$ gas evolution at high applied current density, the corrective term $\alpha$ introduced in Eq. (10) and Eq. (23) was taken at 7.5\% to fit experimental results. This tells that approximately only $7.5 \%$ of cathode surface was effective for mineral electroprecipitation including the detachment of deposits already formed by the evolving gas. The $\alpha$ value was found to approximately match the observed experimental decrease of $\mathrm{CaCO}_{3}$ scaling $(7.2 \%)$ between the two regions of applied current densities investigated. In addition, it has also been observed that at lower applied current, the applied current density already surpassed limiting current density (section 4.3). This means that secondary reaction like concurrent gas evolution was already 
present but it did not influence on the availability of interfacial $\mathrm{CO}_{3}{ }^{2-}$ on cathode (Fig. 6(b)) but rather improving the mass transport of $\mathrm{Ca}^{2+}$ and $\mathrm{Mg}^{2+}$ towards cathode surface (section 4.4.1). The hindrance of $\mathrm{CaCO}_{3}$ growth kinetics in this case was purely attributed to steric inhibition of $\mathrm{Mg}^{2+}$ in solution since no $\mathrm{Mg}(\mathrm{OH})_{2}$ was produced under this condition [81]. Therefore, the kinetic law of depositing $\mathrm{CaCO}_{3}$ was slightly modified taking into account this effect as defined in Eq. (32):

$r_{\mathrm{Ca}^{2+}}=-r_{\mathrm{CaCO}_{3}}=-\left(k_{\mathrm{CaCO}_{3}}-k_{\text {inhib }}\right)\left[\mathrm{Ca}^{2+}\right]\left[\mathrm{CO}_{3}^{2-}\right]_{\text {int }, \mathrm{t}}$

where $k_{\text {inhib }}$ (in $\mathrm{m}^{3} \mathrm{~mol}^{-1} \mathrm{~min}^{-1}$ ) is the steric inhibition of $\mathrm{Mg}^{2+}$ ion either by adsorption or incorporation into $\mathrm{CaCO}_{3}$ lattices as previously discussed in section 4.4.2. By fitting the modeled $\mathrm{Ca}^{2+}$ concentration with its experimental data (the matrix in presence of $\mathrm{Mg}^{2+}$ ) at low applied current density, $k_{\text {inhib }}$ was evaluated to be $9.0 \times 10^{-4} \mathrm{~m}^{3} \mathrm{~mol}^{-1} \mathrm{~min}^{-1}$. This value is about $25 \%$ of the empirical $\mathrm{CaCO}_{3}$ electro-precipitation constant of $k_{\mathrm{CaCO}_{3}}$. It suggests that in the presence of $5 \mathrm{mg} \mathrm{L}^{-1} \mathrm{of} \mathrm{Mg}^{2+}$ (in the system containing $150 \mathrm{mg} \mathrm{L}^{-1}$ of $\mathrm{Ca}^{2+}$ ), $25 \%$ less $\mathrm{CaCO}_{3}$ electro-precipitation should have been observed due to the inhibition effect. However, experimental results indicated only $12 \%$ less $\mathrm{CaCO}_{3}$ scaling after 5 hours of electrolysis, which is about half the theoretical value. This discrepancy was attributed to the enhancement of $\mathrm{Ca}^{2+}, \mathrm{CO}_{3}{ }^{2-}$ and $\mathrm{Mg}^{2+}$ transport by micro- and macro-convection towards cathode interface [73-76] which could favor the electro-precipitation reactions.

\section{Conclusions}

The occurrence of mineral electro-precipitation inside a microfluidic reactor was newly investigated in this work. Due to the existence of precipitating agents in water resources of natural or anthropogenic origin, electro-precipitates can be formed during advanced electro-oxidation processes and they might compromise the efficiency of such processes. Inside a scalable microfluidic reactor equipped with BDD, the phenomenon of local alkalization on cathode surface originated principally from reduction of water and not dissolved $\mathrm{O}_{2}$ under investigated conditions. The reaction kinetics at the proximity of cathode surface were limited by mass transport. Upon further investigation, the 
influence of electromigration towards the occurrence of electro-precipitation was negligible, meaning that diffusion was the main limiting factor.

$\mathrm{MgCO}_{3}$ deposit was not observed throughout this work, while $\mathrm{Mg}(\mathrm{OH})_{2}$ precipitate was highly dependent on applied current density, because the local $\mathrm{pH}$ value was the decisive parameter upon its formation. Thus $\mathrm{Mg}(\mathrm{OH})_{2}$ was hardly formed at low applied current density. In addition, $\mathrm{Mg}(\mathrm{OH})_{2}$ deposition was independent of ionic species jointly present in the electrolyte bulk. Regarding Cabased precipitates, $\mathrm{Ca}(\mathrm{OH})_{2}$ was not formed under our investigated configuration, while $\mathrm{CaCO}_{3}$ was easily deposited on the surface of cathode even under small current polarization. More electroprecipitation of $\mathrm{CaCO}_{3}$ was recovered at lower current density $\left(0.4 \mathrm{~mA} \mathrm{~cm}{ }^{-2}\right)$ owing to vigorous gas evolution at higher applied current density $\left(4 \mathrm{~mA} \mathrm{~cm}^{-2}\right) . \mathrm{CaCO}_{3}$ scaling was proven to be impeded by the presence of $\mathrm{Mg}^{2+}$ ion. A novel mathematical model was proposed to simulate and predict the evolution of depositing species of $\mathrm{Mg}^{2+}, \mathrm{Ca}^{2+}$ and interfacial $\mathrm{CO}_{3}{ }^{2-}$ in presence or absence of codeposition within the microfluidic reactor. The models fitted well with experimental data given the RMSE, ME and IOA values.

It could be deduced eventually that ${ }^{\circ} \mathrm{OH}$ continuously produced on BDD anode did not influence towards the electro-precipitation occurring on cathode counterpart in the applied condition despite micrometric distance separating them. In order to minimize scaling formation, a compromise with respect to degradation efficiency of pollutant needs to be accommodated for upcoming research. Lower applied current density could be used, but lower degradation of pollutant via direct electron transfer or indirect oxidation would be consequently expected due to lower overpotential. Alternatively, mineral electro-precipitation could be minimized by applying high current density, benefiting the intensified evolving gas on cathode surface to un-do the deposits. However, energy consumption would be deemed deal-breaker for its application at industrial scale. Nonetheless, since micrometric range of inter-electrode distance extensively cut down the internal resistance of electrochemical cells, cell voltage would not be eventually so high at such high current densities. 
803 Further studies are required to test microfluidic configuration in order to concomitantly yield high 804 degradation efficiency while minimizing the resulting mineral electro-precipitation.

\section{Acknowledgments}

806 Authors would like to express their gratitude to French ministry of higher education and research 807 (MESRI) for financial funding of doctoral contract of Faidzul Hakim Adnan as well as financial 808 support received from Carnot ICEEL, LTSER Zone Atelier du bassin de la Moselle (ZAM) and 809 European regional development fund program (CPER SusChemProc). 
811 [1] S.D. Richardson, S.Y. Kimura, Water analysis: Emerging contaminants and current issues, 812 Analytical Chemistry, 88 (2016) 546-582.

813 [2] B. Petrie, R. Barden, B. Kasprzyk-Hordern, A review on emerging contaminants in wastewaters 814 and the environment: Current knowledge, understudied areas and recommendations for future monitoring, Water Research, 72 (2015) 3-27.

[3] M.A. Oturan, J.-J. Aaron, Advanced oxidation processes in water/wastewater treatment: Principles and applications. A review, Critical Reviews in Environmental Science and Technology, 44 (2014) 2577-2641.

[4] H. Monteil, Y. Péchaud, N. Oturan, M.A. Oturan, A review on efficiency and cost effectiveness of electro-and bio-electro-fenton processes: Application to the treatment of pharmaceutical pollutants in water, Chemical Engineering Journal, 376 (2019) 119577.

[5] C.A. Martínez-Huitle, M.A. Rodrigo, I. Sirés, O. Scialdone, Single and coupled electrochemical processes and reactors for the abatement of organic water pollutants: A critical review, Chemical Reviews, 115 (2015) 13362-13407.

[6] F.C. Moreira, R.A.R. Boaventura, E. Brillas, V.J.P. Vilar, Electrochemical advanced oxidation processes: A review on their application to synthetic and real wastewaters, Applied Catalysis B: Environmental, 202 (2017) 217-261.

[7] E. Mousset, N. Oturan, M.A. Oturan, An unprecedented route of OH radical reactivity evidenced by an electrocatalytical process: Ipso-substitution with perhalogenocarbon compounds, Applied Catalysis B: Environmental, 226 (2018) 135-146.

[8] E. Mousset, Y. Pechaud, N. Oturan, M.A. Oturan, Charge transfer/mass transport competition in advanced hybrid electrocatalytic wastewater treatment: Development of a new current efficiency relation, Applied Catalysis B: Environmental, 240 (2019) 102-111.

[9] P.V. Nidheesh, G. Divyapriya, N. Oturan, C. Trellu, M.A. Oturan, Environmental applications of boron-doped diamond electrodes: 1. Applications in water and wastewater treatment, ChemElectroChem, 6 (2019) 2124-2142.

[10] O. Scialdone, A. Galia, C. Guarisco, S. Randazzo, G. Filardo, Electrochemical incineration of oxalic acid at boron doped diamond anodes: Role of operative parameters, Electrochimica Acta, 53 (2008) 2095-2108.

[11] O. Scialdone, E. Corrado, A. Galia, I. Sirés, Electrochemical processes in macro and microfluidic cells for the abatement of chloroacetic acid from water, Electrochimica Acta, 132 (2014) 15-24.

[12] O. Scialdone, A. Galia, S. Sabatino, D. Mira, C. Amatore, Electrochemical conversion of dichloroacetic acid to chloroacetic acid in a microfluidic stack and in a series of microfluidic reactors, ChemElectroChem, 2 (2015) 684-690.

[13] E. Mousset, Unprecedented reactive electro-mixing reactor: Towards synergy between microand macro-reactors?, Electrochemistry Communications, 118 (2020) 106787.

[14] J.F. Pérez, J. Llanos, C. Sáez, C. López, P. Cañizares, M.A. Rodrigo, Development of an innovative approach for low-impact wastewater treatment: A microfluidic flow-through electrochemical reactor, Chemical Engineering Journal, 351 (2018) 766-772.

[15] P. Ma, H. Ma, S. Sabatino, A. Galia, O. Scialdone, Electrochemical treatment of real wastewater. Part 1: Effluents with low conductivity, Chemical Engineering Journal, 336 (2018) 133-140.

[16] E. Mousset, M. Puce, M.N. Pons, Advanced electro-oxidation with boron-doped diamond for acetaminophen removal from real wastewater in a microfluidic reactor: Kinetics and mass-transfer studies, ChemElectroChem, 6 (2019) 2908-2916.

[17] F. Sopaj, N. Oturan, J. Pinson, F. Podvorica, M.A. Oturan, Effect of the anode materials on the efficiency of the electro-fenton process for the mineralization of the antibiotic sulfamethazine, Applied Catalysis B: Environmental, 199 (2016) 331-341. 
[18] L. Beaunier, C. Gabrielli, G. Poindessous, G. Maurin, R. Rosset, Investigation of electrochemical calcareous scaling: Nuclei counting and morphology, Journal Of Electroanalytical Chemistry, 501 (2001) 41-53.

[19] C. Deslouis, D. Festy, O. Gil, G. Rius, S. Touzain, B. Tribollet, Characterization of calcareous deposits in artificial sea water by impedance techniques - 1 . Deposit of $\mathrm{CaCO}_{3}$ without $\mathrm{Mg}(\mathrm{OH})_{2}$, Electrochimica Acta, 43 (1998) 1891-1901.

[20] C. Deslouis, I. Frateur, G. Maurin, B. Tribollet, Interfacial pH measurement during the reduction of dissolved oxygen in a submerged impinging jet cell, Journal of Applied Electrochemistry, 27 (1997) 482-492.

[21] H. Deligianni, L.T. Romankiw, In situ surface pH measurement during electrolysis using a rotating pH electrode, IBM Journal of Research and Development, 37 (1993) 85-95.

[22] J. Marin-Cruz, R. Cabrera-Sierra, M. Pech-Canul, I. Gonzalez, EIS study on corrosion and scale processes and their inhibition in cooling system media, Electrochimica Acta, 51 (2006) 1847-1854.

[23] J. Marin-Cruz, E. Garcia-Figueroa, M. Miranda-Hernández, I. Gonzalez, Electrochemical treatments for selective growth of different calcium carbonate allotropic forms on carbon steel, Water Research, 38 (2004) 173-183.

[24] Y. Ben Amor, L. Bousselmi, H. Takenouti, E. Triki, Influence of sulphate ions on corrosion mechanism of carbon steel in calcareous media, Corrosion Engineering, Science and Technology, 40 (2005) 129-136.

[25] Y. Ben Amor, L. Bousselmi, B. Tribollet, E. Triki, Study of the effect of magnesium concentration on the deposit of allotropic forms of calcium carbonate and related carbon steel interface behavior, Electrochimica Acta, 55 (2010) 4820-4826.

[26] L. Bousselmi, C. Fiaud, B. Tribollet, E. Triki, Impedance spectroscopic study of a steel electrode in condition of scaling and corrosion: Interphase model, Electrochimica Acta, 44 (1999) 4357-4363. [27] L. Bousselmi, C. Fiaud, B. Tribollet, E. Triki, The characterisation of the coated layer at the interface carbon steel-natural salt water by impedance spectroscopy, Corrosion Science, 39 (1997) 1711-1724.

[28] Z. Belarbi, B. Sotta, L. Makhloufi, B. Tribollet, J. Gamby, Modelling of delay effect of calcium carbonate deposition kinetics on rotating disk electrode in the presence of green inhibitor, Electrochimica Acta, 189 (2016) 118-127.

[29] M. Euvrard, F. Membrey, C. Filiatre, C. Pignolet, A. Foissy, Kinetic study of the electrocrystallization of calcium carbonate on metallic substrates, Journal Of Crystal Growth, 291 (2006) 428-435.

[30] C. Deslouis, D. Festy, O. Gil, V. Maillot, S. Touzain, B. Tribollet, Characterization of calcareous deposits in artificial sea water by impedances techniques: 2-deposit of $\mathrm{Mg}(\mathrm{OH})_{2}$ without $\mathrm{CaCO}_{3}$, Electrochimica Acta, 45 (2000) 1837-1845.

[31] R. Jaouhari, A. Benbachir, A. Guenbour, C. Gabrielli, J. Garcia-Jareno, G. Maurin, Influence of water composition and substrate on electrochemical scaling, Journal of The Electrochemical Society, 147 (2000) 2151.

[32] A. Martinod, A. Neville, M. Euvrad, K. Sorbie, Electrodeposition of a calcareous layer: Effects of green inhibitors, Chemical Engineering Science, 64 (2009) 2413-2421.

[33] C. Deslouis, P. Falaras, O. Gil, M. Jeannin, V. Maillot, B. Tribollet, Influence of clay on calcareous deposit in natural and artificial sea water, Electrochimica Acta, 51 (2006) 3173-3180.

[34] S.-H. Lin, S.C. Dexter, Effects of temperature and magnesium ions on calcareous deposition, Corrosion, 44 (1988) 615-622.

[35] J. Marin-Cruz, R. Cabrera-Sierra, M. Pech-Canul, I. Gonzalez, Characterization of different allotropic forms of calcium carbonate scales on carbon steel by electrochemical impedance spectroscopy, Journal of Applied Electrochemistry, 34 (2004) 337-343.

[36] S.M. Hoseinieh, T. Shahrabi, Influence of ionic species on scaling and corrosion performance of AISI 316L rotating disk electrodes in artificial seawater, Desalination, 409 (2017) 32-46.

[37] S.M. Hoseinieh, T. Shahrabi, B. Ramezanzadeh, M.F. Rad, The role of porosity and surface morphology of calcium carbonate deposits on the corrosion behavior of unprotected API 5L X52 
rotating disk electrodes in artificial seawater, Journal of The Electrochemical Society, 163 (2016) C515-C529.

[38] F. Sopaj, N. Oturan, J. Pinson, F.I. Podvorica, M.A. Oturan, Effect of cathode material on electrofenton process efficiency for electrocatalytic mineralization of the antibiotic sulfamethazine, Chemical Engineering Journal, 384 (2020) 123249.

[39] S. Mathé, Chimie des solutions, Dunod2018.

[40] W.M. Haynes, CRC Handbook of chemistry and physics, 97th ed., CRC press, 2017.

[41] H. Vogt, R.J. Balzer, The bubble coverage of gas-evolving electrodes in stagnant electrolytes, Electrochimica Acta, 50 (2005) 2073-2079.

[42] C. Barchiche, C. Deslouis, D. Festy, O. Gil, P. Refait, S. Touzain, B. Tribollet, Characterization of calcareous deposits in artificial seawater by impedance techniques: 3 - deposit of $\mathrm{CaCO}_{3}$ in the presence of $\mathrm{Mg}(\mathrm{II})$, Electrochimica Acta, 48 (2003) 1645-1654.

[43] M. Piri, R. Arefinia, Investigation of the hydrogen evolution phenomenon on $\mathrm{CaCO}_{3}$ precipitation in artificial seawater, Desalination, 444 (2018) 142-150.

[44] O. Scialdone, A. Galia, S. Sabatino, Electro-generation of $\mathrm{H}_{2} \mathrm{O}_{2}$ and abatement of organic pollutant in water by an electro-fenton process in a microfluidic reactor, Electrochemistry Communications, 26 (2013) 45-47.

[45] J. Newman, K.E. Thomas-Alyea, Electrochemical systems, 3rd ed., John Wiley \& Sons, 2012.

[46] O. Velts, M. Uibu, J. Kallas, R. Kuusik, $\mathrm{CO}_{2}$ mineral trapping: Modeling of calcium carbonate precipitation in a semi-batch reactor, Energy Procedia, 4 (2011) 771-778.

[47] S.J. Kakaraniya, A. Mehra, Reactive precipitation in gas-liquid systems, Industrial \& Engineering Chemistry Research, 46 (2007) 1125-1137.

[48] C. Kazadi Mbamba, D.J. Batstone, X. Flores-Alsina, S. Tait, A generalised chemical precipitation modelling approach in wastewater treatment applied to calcite, Water Research, 68 (2015) 342-353.

[49] Y. Zhang, R.A. Dawe, Influence of $\mathrm{Mg}^{2+}$ on the kinetics of calcite precipitation and calcite crystal morphology, Chemical Geology, 163 (2000) 129-138.

[50] M. Ben Amor, D. Zgolli, M.M. Tlili, A.S. Manzola, Influence of water hardness, substrate nature and temperature on heterogeneous calcium carbonate nucleation, Desalination, 166 (2004) 79-84.

[51] J.N. Butler, Carbon dioxide equilibria and their applications, 1st ed., Taylor \& Francis Group, New York: Routledge, 1991.

[52] P. Bénézeth, G.D. Saldi, J.-L. Dandurand, J. Schott, Experimental determination of the solubility product of magnesite at 50 to $200^{\circ} \mathrm{C}$, Chemical Geology, 286 (2011) 21-31.

[53] P. Reichert, AQUASIM - a tool for simulation and data analysis of aquatic systems, Water Science and Technology, 30 (1994) 21.

[54] E. Mousset, S. Pontvianne, M.-N. Pons, Fate of inorganic nitrogen species under homogeneous fenton combined with electro-oxidation/reduction treatments in synthetic solutions and reclaimed municipal wastewater, Chemosphere, 201 (2018) 6-12.

[55] C.A. Martínez-Huitle, M. Panizza, Electrochemical oxidation of organic pollutants for wastewater treatment, Current Opinion in Electrochemistry, 11 (2018) 62-71.

[56] E. Mousset, L. Quackenbush, C. Schondek, A. Gerardin-Vergne, S. Pontvianne, S. Kmiotek, M.N. Pons, Effect of homogeneous Fenton combined with electron transfer on the fate of inorganic chlorinated species in synthetic and reclaimed municipal wastewater, Electrochimica Acta, 334 (2020) 135608.

[57] E. Mousset, D.D. Dionysiou, Photoelectrochemical reactors for treatment of water and wastewater: a review, Environmental Chemistry Letters, 18 (2020) 1301-1318.

[58] N. Vatistas, C. Comninellis, The persulfate process for the mediated oxidation of organic pollutants, in: C. Comninellis, G. Chen (Eds.) Electrochemistry for the Environment, Springer New York, New York, NY, 2010, pp. 229-244.

[59] B.P. Chaplin, Critical review of electrochemical advanced oxidation processes for water treatment applications, Environmental Science: Processes \& Impacts, 16 (2014) 1182-1203. 
[60] B.P. Chaplin, Chapter 17 - Advantages, disadvantages, and future challenges of the use of electrochemical technologies for water and wastewater treatment, in: C.A. Martínez-Huitle, M.A. Rodrigo, O. Scialdone (Eds.) Electrochemical Water and Wastewater Treatment, ButterworthHeinemann, 2018, pp. 451-494.

[61] A.R. Despić, Deposition and dissolution of metals and alloys. Part B: Mechanisms, kinetics, texture, and morphology, in: B.E. Conway, J.O.M. Bockris, E. Yeager, S.U.M. Khan, R.E. White (Eds.) Comprehensive Treatise of Electrochemistry: Volume 7 Kinetics and Mechanisms of Electrode Processes, Springer US, Boston, MA, 1983, pp. 451-528.

[62] H. Karoui, B. Riffault, M. Jeannin, A. Kahoul, O. Gil, M. Ben Amor, M.M. Tlili, Electrochemical scaling of stainless steel in artificial seawater: Role of experimental conditions on $\mathrm{CaCO}_{3}$ and $\mathrm{Mg}(\mathrm{OH}) 2$ formation, Desalination, 311 (2013) 234-240.

[63] A.J. Bard, L.R. Faulkner, Electrochemical methods: Fundamentals and applications, John Wiley \& Sons2001.

[64] M.M. Tlili, M. Benamor, C. Gabrielli, H. Perrot, B. Tribollet, Influence of the interfacial pH on electrochemical $\mathrm{CaCO}_{3}$ precipitation, Journal of The Electrochemical Society, 150 (2003) C765.

[65] S. Sarkar, W. Aquino, Electroneutrality and ionic interactions in the modeling of mass transport in dilute electrochemical systems, Electrochimica Acta, 56 (2011) 8969-8978.

[66] T. Li, T.C. Keener, L. Cheng, Carbon dioxide removal by using $\mathrm{Mg}(\mathrm{OH}) 2$ in a bubble column: Effects of various operating parameters, International Journal of Greenhouse Gas Control, 31 (2014) 67-76.

[67] M. Panizza, P.A. Michaud, G. Cerisola, C. Comninellis, Anodic oxidation of 2-naphthol at boron-doped diamond electrodes, Journal Of Electroanalytical Chemistry, 507 (2001) 206-214.

[68] P. Cañizares, J. García-Gómez, I. Fernández de Marcos, M.A. Rodrigo, J. Lobato, Measurement of mass-transfer coefficients by an electrochemical technique, Journal Of Chemical Education, 83 (2006) 1204.

[69] R.A.W. Dryfe, 20 - Liquid junction potentials, in: C.G. Zoski (Ed.) Handbook of Electrochemistry, Elsevier, Amsterdam, 2007, pp. 849-877.

[70] C. Barchiche, C. Deslouis, O. Gil, P. Refait, B. Tribollet, Characterisation of calcareous deposits by electrochemical methods: Role of sulphates, calcium concentration and temperature, Electrochimica Acta, 49 (2004) 2833-2839.

[71] T. Okstad, Ø. Rannestad, R. Johnsen, K. Nisancioglu, Significance of hydrogen evolution during cathodic protection of carbon steel in seawater, Corrosion, 63 (2007) 857-865.

[72] C. Arkam, Quartz crystal electrogravimetry with controlled hydrodynamics, Journal of The Electrochemical Society, 141 (1994) L103.

[73] H. Vogt, The role of single-phase free convection in mass transfer at gas evolving electrodes 1. Theoretical, Electrochimica Acta, 38 (1993) 1421-1426.

[74] H. Vogt, Gas-evolving electrodes, in: E. Yeager, J.O.M. Bockris, B.E. Conway, S. Sarangapani (Eds.) Comprehensive Treatise of Electrochemistry: Electrodics: Transport, Springer US, Boston, MA, 1983, pp. 445-489.

[75] L.J.J. Janssen, Behaviour of and mass transfer at gas-evolving electrodes, Electrochimica Acta, 34 (1989) 161-169.

[76] M.G. Fouad, G.H. Sedahmed, Mass transfer at gas evolving screen electrodes, Electrochimica Acta, 20 (1975) 615-618.

[77] C. Gabrielli, G. Maurin, G. Poindessous, R. Rosset, Nucleation and growth of calcium carbonate by an electrochemical scaling process, Journal Of Crystal Growth, 200 (1999) 236-250.

[78] Y. Ben Amor, L. Bousselmi, M.C. Bernard, B. Tribollet, Nucleation-growth process of calcium carbonate electrodeposition in artificial water - influence of the sulfate ions, Journal Of Crystal Growth, 320 (2011) 69-77.

[79] T. Chen, A. Neville, M. Yuan, Calcium carbonate scale formation — assessing the initial stages of precipitation and deposition, Journal of Petroleum Science and Engineering, 46 (2005) 185-194.

[80] M. Kitamura, Crystallization and transformation mechanism of calcium carbonate polymorphs and the effect of magnesium ion, Journal Of Colloid And Interface Science, 236 (2001) 318-327. 
1013 [81] K.E. Mantel, W.H. Hartt, T.-Y. Chen, Substrate, surface finish, and flow rate influences on 1014 calcareous deposit structure, Corrosion, 48 (1992) 489-500.

1015 [82] C. Gabrielli, Quartz crystal microbalance investigation of electrochemical calcium carbonate 1016 scaling, Journal of The Electrochemical Society, 145 (1998) 2386.

1017 [83] S. $\mathrm{Xu}$, Structure and morphology of electrodeposited $\mathrm{CaCO}_{3}$ : X-ray diffraction and microscopy 1018 studies, Journal of The Electrochemical Society, 146 (1999) 3315.

1019 [84] C. Gabrielli, M. Keddam, A. Khalil, R. Rosset, M. Zidoune, Study of calcium carbonate scales 1020 by electrochemical impedance spectroscopy, Electrochimica Acta, 42 (1997) 1207-1218.

1021 [85] H.J. Meyer, The influence of impurities on the growth rate of calcite, Journal Of Crystal Growth, 102266 (1984) 639-646.

1023 [86] F.L. Sayles, W.S. Fyfe, The crystallization of magnesite from aqueous solution, Geochimica et 1024 Cosmochimica Acta, 37 (1973) 87-99.

1025 [87] L. Hopkinson, K. Rutt, G. Cressey, The transformation of nesquehonite to hydromagnesite in 1026 the system $\mathrm{CaO}-\mathrm{MgO}-\mathrm{H}_{2} \mathrm{O}-\mathrm{CO}_{2}$ : An experimental spectroscopic study, The Journal of Geology, 116 1027 (2008) 387-400.

1028 [88] M. Hänchen, V. Prigiobbe, R. Baciocchi, M. Mazzotti, Precipitation in the Mg-carbonate system 1029 - effects of temperature and $\mathrm{CO}_{2}$ pressure, Chemical Engineering Science, 63 (2008) 1012-1028. 